\title{
ATP-evoked Increases in Intracellular Calcium in Neurons and Glia from the Dorsal Spinal Cord
}

\author{
Michael W. Salter ${ }^{1,2}$ and Janice L. Hicks ${ }^{1}$ \\ 'Division of Neuroscience, Hospital for Sick Children, and 2Department of Physiology, University of Toronto, Toronto, \\ Ontario, Canada M5G $1 \times 8$
}

\begin{abstract}
ATP has been proposed as a possible chemical mediator of synaptic transmission in the spinal dorsal horn on the basis that it is released in dorsal horn synaptosomes in a $\mathrm{Ca}^{2+}$. dependent manner and that its effects mimic those of synaptic inputs to dorsal horn neurons. In the present study we examined the actions of ATP on neurons and glia in cell culture using optical and electrophysiological recording techniques. We found that ATP increased intracellular $\mathrm{Ca}^{2+}$ concentration $\left(\left[\mathrm{Ca}^{2+}\right]_{j}\right)$ in $>99 \%$ of astrocytes. In contrast, only $35 \%$ of neurons and $20 \%$ of oligodendrocytes responded to ATP. The prevalence of the ATP-evoked response in astrocytes led us to characterize the type of receptor mediating the response, the source of $\mathrm{Ca}^{2+}$, and the membrane currents activated by ATP. We found that ADP was approximately equipotent with ATP in increasing $\left[\mathrm{Ca}^{2+}\right]_{i}$ whereas AMP and adenosine had no effect. In addition, responses to ATP were blocked in a concentration-dependent manner by the $P_{2}$ purinergic receptor antagonist suramin. Furthermore, as it was found that 2-methylthio-ATP was more potent than ATP and that $\beta, \gamma$-methylene-ATP was ineffective, the responses were mediated via the $P_{2 Y}$ subtype of purinergic receptor. The increase in $\left[\mathrm{Ca}^{2+}\right]$, evoked by ATP persisted in extracellular medium with no added $\mathrm{Ca}^{2+}$ and containing EGTA, indicating that this increase was due to release of $\mathrm{Ca}^{2+}$ from intracellular stores. Release of $\mathrm{Ca}^{2+}$ by ATP was blocked by thapsigargin but was unaffected by caffeine. ATP had several effects on membrane current activating inward, outward, and mixed currents despite uniformly causing increases in $\left[\mathrm{Ca}^{2+}\right]_{r}$. These observations indicate that ATP has diverse electrophysiological effects on astrocytes as well as increasing $\left[\mathrm{Ca}^{2+}\right]_{i}$ in these cells. We speculate that ATP released from synaptic terminals in the dorsal horn might act not only on postsynaptic neurons but also on perisynaptic astrocytes. Thus, a physiological role for ATP may be as a neuronal-glial signaling molecule within the spinal dorsal horn.
\end{abstract}

\footnotetext{
Received Mar. 23, 1993; revised Aug. 17, 1993; accepted Aug. 26, 1993.

This work was supported by Grant MT-11219 from the Medical Research Council of Canada to M.W.S. and by the Nicole Fealdman Memorial Fund. M.W.S. is an MRC Scholar. We thank Drs. J. F. MacDonald and Y. De Koninck for critical reading of the manuscript, and Ms. Kathleen Downie for assistance preparing the manuscript. We gratefully acknowledge Dr. J. Cobby at Bayer Canada Inc. for providing suramin. Ms. Lise Aasheim participated in some of the experiments.

Correspondence should be addressed to Dr. Michael W. Salter, Division of Neuroscience, The Hospital for Sick Children, 555 University Avenue, Toronto, Ontario, Canada M5G 1 X8.

Copyright (C) 1994 Society for Neuroscience $0270-6474 / 94 / 141563-13 \$ 05.00 / 0$
}

[Key words: fura-2, dorsal horn neurons, $P_{2}$ purinergic receptors, patch-clamp recording, thapsigargin, caffeine, suramin]

ATP has well-known roles in intracellular energy metabolism. However, ATP is released as well from many types of cell and has been suggested as an intercellular signaling molecule in a number of systems including the PNS and CNS (Phillis and Wu, 1981; Stone, 1981; Burnstock, 1990). In the peripheral sympathetic nervous system, ATP appears to mediate fast excitatory junctional potentials at neuromuscular synapses in the vas deferens (Sneddon et al., 1982) and vascular smooth muscle (Sneddon and Burnstock, 1984; Benham, 1989). ATP has been implicated as a mediator of excitatory synaptic transmission at sympathetic neuron-neuron synapses, specifically in the coeliac ganglion (Evans et al., 1992; Silinsky et al., 1992). It has been suggested that ATP might also be an excitatory chemical mediator in the CNS (Phillis and $\mathrm{Wu}, 1981$ ), and recently evidence for excitatory postsynaptic currents mediated by ATP has been obtained in the medial habenula (Edwards et al., 1992).

The spinal cord was the first region in the CNS where ATP was implicated as a chemical mediator of synaptic transmission. On the basis of evidence that stimulation of primary sensory neurons causes release of ATP in the periphery, Holton and Holton suggested that ATP might also be released from the central terminals of these neurons (Holton and Holton, 1954; Holton, 1959). Subsequently ATP was found to be released in a $\mathrm{Ca}^{2+}$-dependent manner from synaptosomes from the dorsal horn of the spinal cord (White et al., 1985) and to have excitatory effects on dorsal horn neurons in vivo (Fyffe and Perl, 1984; Salter and Henry, 1985) and in vitro (Jahr and Jessell, 1983). Thus, it has becn proposed that a physiological role for ATP might be as a mediator of excitatory synaptic transmission in the dorsal horn (for review, see Salter et al., 1993).

ATP has been found to increase intracellular $\mathrm{Ca}^{2+}$ concentration $\left(\left[\mathrm{Ca}^{2+}\right]_{i}\right)$ in a variety of excitable and nonexcitable cells (O'Connor et al., 1991; El-Moatassim et al., 1992). Two principal mechanisms by which ATP increases $\left[\mathrm{Ca}^{2+}\right]_{i}$ have been described: influx of $\mathrm{Ca}^{21}$ through ligand-gated ion channels activated by ATP (Benham and Tsien, 1987) and release of $\mathrm{Ca}^{2+}$ from intracellular stores (Harden et al., 1990). Subtypes of receptor for ATP ( $\mathrm{P}_{2}$ purinergic receptors) have been identified that are coupled to channels permeable to $\mathrm{Ca}^{2+}$, including $\mathrm{P}_{2 \mathrm{x}}$, $P_{2 T}$, and $P_{22}$ receptors (Burnstock, 1990; Bean, 1992), or to G-protein-mediated second messenger mechanisms for release of $\mathrm{Ca}^{2+}$ from intracellular stores, including $\mathrm{P}_{2 Y}$ and $\mathrm{P}_{2 \mathrm{U}}$ receptors (Harden et al., 1990; O'Connor et al., 1991). As the effects of 
ATP on $\left[\mathrm{Ca}^{2+}\right]_{i}$ in the dorsal horn have not been examined, one purpose of the present study was to determine the effects of ATP on $\left[\mathrm{Ca}^{2+}\right]$ in dorsal horn neurons. It is clear, however, that expression of receptors for neurotransmitters is not limited to neurons but rather that glia express a variety of neurotransmitter receptors (for review, see Hösli and Hösli, 1993). Therefore, we also examined the effects of ATP on glia from the dorsal spinal cord.

We report here that ATP increases $\left[\mathrm{Ca}^{2+}\right]_{i}$ in about one-third of ncurons and in greater than $99 \%$ of astrocytes. The responses of astrocytes are characterized in detail and we provide the first direct evidence that $\mathrm{ATP}$ acts on $\mathrm{P}_{2 Y}$ purinergic receptors to release $\mathrm{Ca}^{2+}$ from an intracellular pool that is sensitive to thapsigargin and insensitive to caffeine.

Preliminary results of this study have been reported (Salter, 1992).

\section{Materials and Methods}

Cell cultures. Cultures of dorsal spinal cord were prepared from fetal Wistar rats [embryonic day 16 (E16)-E18]. The fetuses were removed from time-pregnant females (Charles River) immediately after killing by cervical dislocation. Upon removal fetuses were transferred to chilled, sterile Hanks' buffered salt solution and were then killed by decapitation. The entire spinal cord was removed by an anterior approach and was placed dorsal side up in iced Hanks' solution. The meninges and dorsal root ganglia were removed. The dissection procedure used to isolate the dorsal spinal cord was similar to the "open-book" technique of Peterson and Crain (1982). 'The cord was opened by incising it through the dorsal commissure to the central canal along the entire length. The opened cord was turned over and pinned onto a dish coated with Sylgard (DowCorning). The dorsal half of the cord was removed by cutting along the lateral funiculus on each side. The dorsal halves of four cords were pooled, minced and then incubated for $25 \mathrm{~min}$ at $37^{\circ} \mathrm{C}$ in Hanks' solution with trypsin $(0.25 \%)$. The trypsin was inactivated by rinsing the dorsal cords in minimum essential medium with $10 \%$ fetal bovine serum and $10 \%$ horse serum. The tissue was then mechanically dissociated by trituration with two Pasteur pipettes (tip diameters of approximately 500 and $200 \mu \mathrm{m}$ ). The cells were plated onto collagen-coated Aclar 33C plastic that had been attached with Sylgard under a 1 cm hole in a standard $35 \mathrm{~mm}$ culture dish. Aclar $33 \mathrm{C}$ plastic transmits light in the visible, infrared, and near-visible ultraviolet ranges, and is therefore suitable for use when making measurements of $\left[\mathrm{Ca}^{2+}\right]_{i}$ using the UVexcited fluorescent dye fura-2. The culture medium contained minimum essential medium supplemented with $10 \%$ fetal bovine serum, $10 \%$ heatinactivated horse serum, and $1 \mathrm{U} / \mathrm{ml}$ insulin. Four days after plating the cultures were treated for $24 \mathrm{hr}$ with 5 '-fluoro-2-deoxyuridine ( 25 $\mu \mathrm{g} / \mathrm{ml})$ and uridine $(50 \mu \mathrm{g} / \mathrm{ml})$. Two-thirds of the medium in each dish was replaced with fresh media on days 4 and 8 . Cultures were used for recording 6-10 d after plating, when the cell layer was still subconfluent. Media and sera were obtained from GIBCO Canada Inc., Burlington, Ontario.

Recording conditions. Each culture dish was washed thoroughly with an extracellular recording solution containing (mM) NaCl, 140; KCl, 5.4; $N$-2-hydroxyethylpiperazine sulfonic acid (HEPES), 25; glucose, $33 ; \mathrm{CaCl}_{2}, 1.3 ; \mathrm{MgCl}_{2}, 1 ; \mathrm{pH} 7.35$, osmolarity of 310-320 mOsm. Except where indicated, tetrodotoxin (TTX; Sigma) was included in the recording medium at a concentration of $1 \mu \mathrm{M}$ in order to prevent generation of action potentials and thereby to minimize synaptic interactions. In certain experiments $\mathrm{CaCl}_{2}$ or $\mathrm{MgCl}_{2}$ was omitted from the extracellular solution and ethylene glycol bis( $\beta$-aminoethylether)- $N, N, N^{\prime}, N^{\prime}$ tetraacetic acid (EGTA) or ethylene diamine tetracetic acid (EDTA), respectively, was included at a concentration of $0.1 \mathrm{~mm}$. The cultures were placed in the recording chamber and individual cells were observed under Hoffman modulation contrast (Modulation Optics, East Hills, $\mathrm{NY})$. All experiments were done at room temperature $\left(20-22^{\circ} \mathrm{C}\right)$.

Fluorescence measurement of intracellular calcium. Intracellular $\mathrm{Ca}^{2+}$ was measured photometrically from single cells using the fluorescent calcium indicator dye fura-2 (Molecular Probes, Inc., Eugene, OR). After washing thoroughly with recording media, the cells were incubated for 75-90 min at room temperature in recording medium supplemented with fura- 2 acetoxymethyl ester (fura- 2 AM; $2 \mu \mathrm{M}$ ), a membrane-per- meant form of fura- 2 , and $0.5 \%$ bovine serum albumin. The cells were then rinsed thoroughly in the standard extracellular recording media. When this loading protocol was used it appeared that the vast majority of the deesterified dye was localized in a freely diffusible cytoplasmic compartment of the cells, as more than $90 \%$ of the fluorescent signal was lost from the cells by dialysis during whole-cell recordings if fura-2 was not included in the intracellular solution. When fura-2 $(50 \mu \mathrm{M})$ was included in the intracellular solution, the level of fluorescence measured before whole-cell recording was divided by that measured at steady state after intracellular dialysis. From this calculation it was estimated that the concentration of the dye in the cells loaded via fura-2 AM was 25$100 \mu \mathrm{M}$. This concentration of dyc would not be expected to significantly affect $\left[\mathrm{Ca}^{2+}\right]_{i}$ (Korn and Horn, 1989).

Excitation light from a $75 \mathrm{~W}$ xenon arc lamp was alternated between 340 and $380 \mathrm{~nm}$ band-pass filters (Omega Optical, Brattleboro, VT) via a mirrored chopper spinning at $60-100 \mathrm{~Hz}$. The light source and chopper (Photon Technologies Inc., London, Ontario) were placed outside a Faraday cage that housed the Nikon Diaphot microscope used in the experiments. The excitation light was recombined in a quartz fiber optic cable coupled to the epifluorescence adapter of the microscope. This cable transmitted essentially no vibration, and hence the light source and chopper were mechanically and electrically isolated from the recording setup. The excitation light was directed toward the cell by means of a DM400 dichroic mirror (Nikon) and was focused through a $40 \times$ Fluor oil-immersion objective (1.3 NA; Nikon). The emitted light passed out of the side port of the microscope and was reflected off a DM580 dichroic mirror mounted in a dual optical path module (Nikon). The light then passed through a $510 \mathrm{~nm}$ band-pass filter and an adjustable rectangular diaphragm that was used to isolate fluorescence from an individual cell. Light was collected by a photomultiplier tube detector, operating in a single photon counting mode, which sent a TTL signal to an IBM PC-compatible computer. Fluorescence signals were typically sampled at rates of $20-100 \mathrm{~Hz}$. Data sampled during the intervals of excitation at 340 and $380 \mathrm{~nm}$ were sorted by the acquisition software. Fluorescence signals were acquired, stored, and analyzed using hardware and osCAR software from Photon Technologies Inc.

Intracellular $\left[\mathrm{Ca}^{2+}\right]$ was determined by the ratio method (Grynkiewicz. et al., 1985) and all calculations were done off line. Raw fluorescence data were digitally filtered using the Savitzky-Golay algorithm (Savitzky and Golay, 1964) using a seven-point buffer. The ratio $(R)$ of the emitted fluorescence at $340: 380 \mathrm{~nm}$ excitation was calculated after subtracting background values measured in a region of the dish that did not contain any cells. Free $\left[\mathrm{Ca}^{2}\right.$ ] was then calculated using the formula

$$
\left[\mathrm{Ca}^{2+}\right]=K\left(R-R_{\min }\right) /\left(R_{\max }-R\right),
$$

where $R_{\min }$ is the minimum ratio corresponding to fully unbound dye, $R_{\max }$ is the maximum ratio for the fully bound dye, and $K$ is the product of the dissociation constant for fura- 2 and the ratio of bound to free dye at $380 \mathrm{~nm}$ excitation. $R_{\min }, R_{\max }$, and $K$ were determined by an in vitro titration calibration using the method described by Grynkiewicz et al. (1985). The buffers used in the titration contained (in $\mathrm{mm}$ ) $\mathrm{KCl}$, 100; HEPES, 10; EGTA, 10; $\pm \mathrm{CaCl}_{2}$, 10; fura-2, 0.005; $\mathrm{pH} 7.26$. Values of $\left[\mathrm{Ca}^{2+}\right]$ in the titration solutions were calculated on the basis of the $\mathrm{Ca}^{2+}:$ EGTA ratio. The $\mathrm{p} K$ values for the stability constants used in the calculations were as follows: $\mathrm{HEGTA}^{3-}, 9.19 ; \mathrm{H}_{2} \mathrm{EGTA}^{2-}, 8.66$;

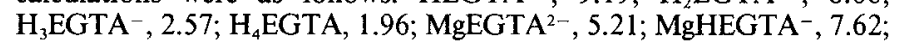
CaEGTA $^{2}$, 10.97; CaHEGTA , 3.79 (Slockbridge, 1987).

The cells were visualized continuously during the period of measuring fluorescence and electrical signals. This was accomplished by transilluminating the cells with light that had been passed through an A600 barrier filter. The transillumination light passed through the DM580 mirror in the dual optical path module and was sent to a CCD camera. The images were observed on a standard television monitor. The cross talk introduced by transilluminating the cells was less than $0.1 \%$ of the typical fluorescence signal and therefore did not interfere with the measurements of $\left[\mathrm{Ca}^{2+}\right]$. In order to maximize the throughput of the fluorescence signal, the Hoffman modulator, which is normally located in the back of the objective, thereby attenuating light transmission by approximately $50 \%$, was repositioned just in front of the CCD camera. Thus, we were able to view the cells under Hoffman modulation contrast while making the fura-2 measurements.

In order to minimize photobleaching of the dye and UV-induced damage of the cells, any unnecessary exposure to UV light was eliminated by closing a shutter located just in front of the arc lamp. This was done at times when cells were recovering between drug applications or 
when solutions were being changed. These intervals, when $\left[\mathrm{Ca}^{2+}\right]_{\text {, could }}$ not be measured, are indicated by small gaps in the records.

Simultaneous electrophysiological recording and $\left[\mathrm{Ca}^{2+}\right]_{i}$ measurement. Patch-clamp recordings in either the whole-cell or perforatedpatch configuration were made while simultaneously measuring $\left[\mathrm{Ca}^{2+}\right]_{i}$. Patch electrodes were constructed from thin-walled borosilicate glass (1.5 mm o.d.; World Precision Instruments). A Brown-Flaming P-87 electrode puller (Sutter Instruments) was used to form electrodes of approximately uniform tip diameter $(1.5-2 \mu \mathrm{m})$. The recording pipettes were fire polished and filled with an intracellular recording solution containing (mM) fura- 2 pentapotassium salt, $0.005 ; \mathrm{KCl}, 140$; HEPES, 10; EGTA, 0.1; $\mathrm{MgCl}_{2}, 1 ; \mathrm{pH}$ 7.26. The low concentration of EGTA was included to prevent overloading the cells with $\mathrm{Ca}^{2+}$ (Thayer et al., 1988).

Perforated-patch recordings (IIorn and Marty, 1988) were made using nystatin (125 $\mu \mathrm{g} / \mathrm{ml}$ ) as described in MacDonald et al. (1993). The pores formed by nystatin are selectively permeable to monovalent ions whereas multivalent ions and molecules with molecular weight greater than 400 are not permeant. During nystatin patch recordings endogenous $\mathrm{Ca}^{2+}$ buffering and metabolic systems appear to remain intact (Korn and Horn, 1989). The pipette solution for nystatin patch recording was that used for whole-cell recordings except fura-2 was not included and the concentration of EGTA was $10 \mathrm{~mm}$. The adequacy of the perforation was assessed by observing the capacitive transients evoked by repeated $10 \mathrm{mV}$ hyperpolarizing voltage steps. After the perforation had stabilized, series resistance was 10-25 M 2 and was compensated approximately $50 \%$.

An EPC-7 amplifier (Adams and List, Westbury, NY) was used for the whole-cell and perforated-patch recordings with currents bcing filtered at $3 \mathrm{kHz}$. Recordings were made using voltage- or current-clamp protocols; the presence of active membrane responses was examined by applying voltage or current steps, respectively. For voltage-clamp experiments the holding potential was $-60 \mathrm{mV}$ unless otherwise indicated Membrane current and voltage recordings were monitored on a chart recorder (Gould Inc.) and were stored along with trigger pulses on videotape (VR 100A; Instrutech Inc., Great Neck, NY). Membrane current, or voltage, recordings were sampled on an analog channel of the hardware used for acquiring the fluorescence data. Trigger pulses for the drug applications were also acquired with this hardware. The trigger pulses were used for display purposes to align records of $\left[\mathrm{Ca}^{2+}\right]_{i}$ measurements with those of membrane current and voltage that were resampled from tape at $0.1-1 \mathrm{kHz}$ on an IBM PC-compatible computer using pCLAMP hardware and softwarc (Axon Instruments, Foster City, CA).

Application of ATP and drugs. ATP, other nucleotides, and drugs were made up as stock solutions that were divided into single-use aliquots and stored at $-70^{\circ} \mathrm{C}$. Aliquots were thawed immediately prior to use and working solutions were made by diluting the stock solution in extracellular recording media. Aqueous stock solutions were used except in the case of thapsigargin which was dissolved in dimethyl sulfoxide (DMSO). The final concentration of DMSO never exceeded $0.1 \%$ and DMSO itself was found to have no effect on $\left[\mathrm{Ca}^{2+}\right]_{i}$ even up to $1 \%$, the maximum concentration tested.

Drugs were applied by pressure (10-50 kPa; Picospritzer II, General Valve, Fairfield, NJ) from glass micropipettes with tips located approximately $20-50 \mu \mathrm{m}$ from the cell study. The experiments were typically done in a static bath and only when specifically indicated were drugs applied in the bath, by exchanging the entire bath volume five or six times.

Suramin was obtained from Bayer Canada Inc.; all other drugs were from Sigma.

Immunocytochemistry and cell markers. Indirect immunofluorescence was done with antibodies to neuron-specitic enolase (NSE), glial fibrillary acidic protein (GFAP), galactocerebroside (GC), or fibronectin. In addition, binding of $\mathrm{B} 4$ lectin, a microglial marker, was examined. One protocol was used for the intracellular markers NSE, GFAP, and fibronectin. A different protocol was used for GC and B4 as the antiGC antibody and B4 lectin bind to membrane sites located extracellularly.

For intracellular labeling the cultures were fixed for $30 \mathrm{~min}$ with $4 \%$ paraformaldehyde after concluding optical or electrophysiological recording. The cultures were washed twice for $15 \mathrm{~min}$ in $0.1 \mathrm{M}$ phosphatebuffered saline (PBS) and then incubated for $15 \mathrm{~min}$ in $10 \%$ normal goat serum. After removing the goat serum, the cultures were incubated for 90 min with the primary antibody in PBS with $0.4 \%$ Triton (PBS-
Triton). Threc subscquent $15 \mathrm{~min}$ washes with PBS were followed by incubation with $10 \%$ normal goat serum in PBS for $15 \mathrm{~min}$. The fluorescently tagged secondary antisera, in PBS-Triton, was then applied for $30 \mathrm{~min}$. The cultures were washed three times with PBS prior to viewing. All washes and incubations were done at room temperature.

For extracellular labeling live cultures were used and these were thoroughly rinsed with extracellular recording medium. In the case of $\mathrm{GC}$, the cultures were then incubated for 15 min with $10 \%$ normal goat serum in the recording medium and washed three times. The cultures were incubated for $60 \mathrm{~min}$ with recording medium containing the primary antibody. Subsequently, three $15 \mathrm{~min}$ washes with recording medium and a 15 min incubation with $10 \%$ normal goat serum were done. The cultures were then incubated for $30 \mathrm{~min}$ with the secondary antisera in the recording medium. Cultures were rinsed thoroughly with recording medium prior to viewing or optical recording. In contrast to the anti-GC antibody, the B4 lectin itself was fluorescently tagged, and therefore a secondary incubation was not required. Hence, for labeling with B4 lectin, the cultures were incubated for 120 min, washed, and then viewed directly.

The following primary antibodies were used as follows: NSE, rabbit polyclonal (Dako Corp., A589); GFAP, rabbit polyclonal (Dako Corp., Z334); GC, mouse monoclonal ascites fluid (Ranscht et al., 1982); and fibronectin, rabbit polyclonal (Calbiochem 341640). Each of these antibodies shows high cross-reactivity with rat tissues. Appropriate dilutions, in the range of 1:50 to 1:400, were established for each of the primary antibodies. The fluorescently labeled secondary antisera were Texas red-conjugated horse anti-rabbit (Dimension Laboratories, TI1000), Texas red-conjugated goat anti-mouse (Dimension Laboratories, TI-2000), and fluorescein isothiocyanate (FITC)-conjugated goat antirabbit (Sigma, F-6005). The final dilutions of the secondary antisera were $1: 100,1: 50$, and 1:500, respectively. B4 lectin conjugated to FITC (Sigma, L2895) was used at a dilution of 1:20. Photographs were taken on Kodak Tmax 400 ASA film.

Correlation of GFAP, NSE, and GC expression with effects of ATP. For GFAP and NSE it was necessary to test cells with ATP before doing immunocytochemistry. To ensure that each cell tested was identified correctly, a photograph of the cell was taken just after testing with ATP and the position of the cell was recorded on a diagram of the field. Also, the number of cells was limited to three or four per dish and the position of each cell was marked on the dish prior to fixation. Cellular morphology was maintained during the processing; thus, after staining each cell was readily identified using the photograph, diagram, and position markings.

For $\mathrm{GC}$, immunocytochemical labeling was done prior to testing ATP. Staining for GC was visualized with secondary antisera conjugated to Texas red. Because neither the excitation nor emission spectra for Texas red overlap with the range of wavelengths used for the fura- 2 measurements, Texas red had no effect on the determination of $\left[\mathrm{Ca}^{2+}\right]_{i}$ in the present studies.

\section{Results}

Recordings of $\left[\mathrm{Ca}^{2+}\right]_{i}$ from 511 individual cells are included in the present report. In all of the experiments, cultures containing neurons and glia were used so that all of the cells studied had been exposed to similar growth conditions. The neurons and glia showed morphological and electrophysiological characteristics typical of these cell types in primary culture (Ransom et al., 1977). Neurons were readily distinguished from glia on the basis of morphological criteria indicated below and recordings were made only from cells that were clearly identified. Neurons generally had a smooth cell body $10-20 \mu \mathrm{m}$ in diameter with two to five processes and grew on top of a layer of background cells. Neurons had resting membrane potentials in the range of -55 to $-70 \mathrm{mV}$, generated action potentials sensitive to TTX, expressed a range of voltage- and ligand-gated currents, and showed spontaneously occurring postsynaptic potentials. Cells identified morphologically as neurons $(n>200)$ expressed NSE (Fig. 1A). The present study includes measurements of $\left[\mathrm{Ca}^{2+}\right]_{\text {i }}$ from 102 neurons; NSE immunofluorescence was found in all of the cells tested $(n=10)$. 

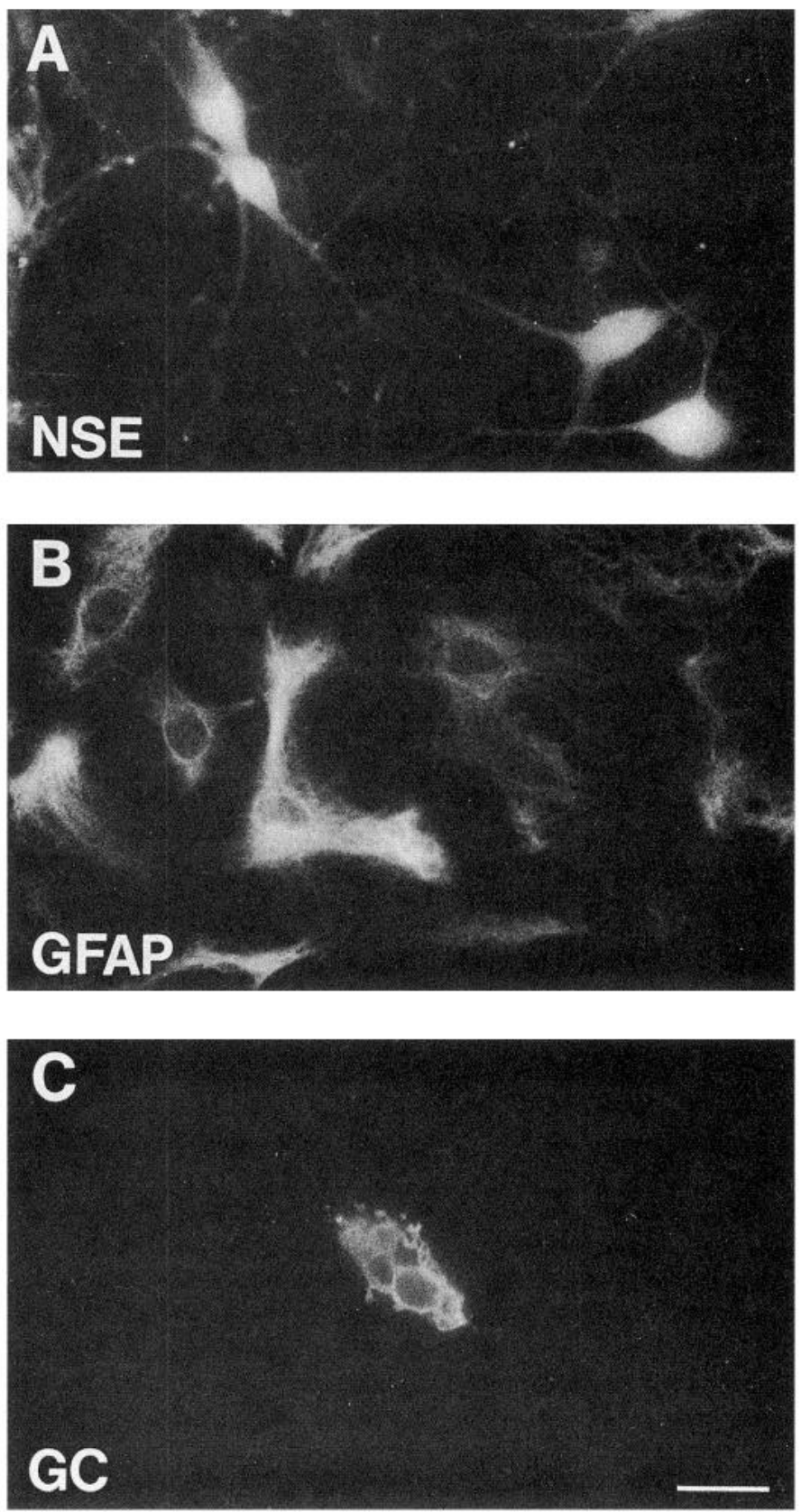

Figure 1. Photomicrographs showing immunoreactivity for NSE $(A)$, GFAP $(B)$, and GC $(C)$ in cultures of dorsal spinal cord. NSE and GFAP were visualized with FITC-conjugated secondary antisera and GC was visualized using a secondary antisera conjugated with Texas red. Scale bar, $25 \mu \mathrm{m}$.

Astrocytes are the predominant glial cell type generally found in primary cultures of dorsal spinal cord (Miller and Szigeti, 1991) and other regions of the CNS (see Hansson and Rönnbäck, 1989). Our cultures of dorsal spinal cord were found to contain large numbers of astrocytes as judged by expression of GFAP $($ Fig. $1 B$ ). These cells were typically irregularly shaped with a large nucleus containing two or more nucleoli. The cells grew directly on the collagen matrix and often had extensive processes. Figure $1 B$ illustrates the diversity in morphology of the GFAPpositive cells commonly observed. Recordings from such cells were always made in subconfluent areas, like that shown in Figure $1 B$, so that individual cells were clearly isolated. The cells had stable resting membrane potentials -60 to $-80 \mathrm{mV}$, did not generate action potentials in the absence of TTX, and did not show spontaneously occurring postsynaptic potentials. Recordings from 394 such cells are included: 32 of these cells were studied with simultaneous patch-clamp recording and fluorescence measurement of $\left[\mathrm{Ca}^{2+}\right]_{;}$; recordings of $\left[\mathrm{Ca}^{2+}\right]_{i}$ alone were made from the remaining cells. In all cases, the cells examined were free from overlying neurons.

The cultures also contained small numbers of glial cells that were immunoreactive for GC (Fig. 1C) and thus appeared to be oligodendrocytes (Ranscht et al., 1982). Such cells had small, oval or round cell bodies with extensive, varicose processes and grew directly on the collagen. Thus, these cells were morphologically distinct from both neurons and astrocytes. GC-positive cells represented less than $1 \%$ of the glial cells in the cultures, consistent with low numbers of oligodendrocytes which have been reported in cultures of E16-E18 dorsal spinal cord (Warf et al., 1991). Intracellular $\left[\mathrm{Ca}^{2+}\right]$ measurements from $15 \mathrm{GC}$ positive cells are reported presently.

\section{Effects of ATP on $\left[\mathrm{Ca}^{2+}\right]_{\mathrm{i}}$ in neurons, astrocytes, and oligodendrocytes}

ATP (1-250 $\mu \mathrm{M}, 10-30 \mathrm{sec})$ caused an increase in $\left[\mathrm{Ca}^{2+}\right]_{i}$ in a subpopulation of neurons. As shown in the example in Figure $2 A$, the rise in $\left[\mathrm{Ca}^{2+}\right]_{i}$ was less than $50 \mathrm{~nm}$, transient, and fully reversible. Responses to ATP were observed in 26 of 74 neurons tested, whereas ATP had no effect on $\left[\mathrm{Ca}^{2+}\right]_{i}$ in the remaining neurons. In contrast, glutamate $(20 \mu \mathrm{M})$ increased $\left[\mathrm{Ca}^{2+}\right]_{i}$ in all neurons tested $(n=15)$. A consistent observation illustrated in Figure $2 A$, which is taken from a neuron with one of the largest responses to ATP, is that the $\left[\mathrm{Ca}^{2+}\right]_{i}$ level at the peak of the response to ATP was much lower than that at the peak of the response to glutamate.

Astrocytes were found to be much more responsive to ATP than were neurons. Recordings of $\left[\mathrm{Ca}^{2+}\right]_{i}$ from a cell that was subsequently found to be immunoreactive for GFAP are shown in Figure $2 B$. ATP $(3 \mu \mathrm{M}, 5 \mathrm{sec})$ caused a large, transient increase in $\left[\mathrm{Ca}^{2+}\right]_{i}$ in this astrocyte. On the other hand, $\left[\mathrm{Ca}^{2+}\right]_{i}$ in this cell was unaffected by glutamate $(200 \mu \mathrm{M})$. All cells confirmed as GFAP positive responded to applications of ATP (1-25 $\mu \mathrm{M}$, 5-20 sec)

An example of the effects of ATP on an oligodendrocyte is illustrated in Figure $2 C$. Applying $10 \mu \mathrm{M}$ ATP to this GC-positive cell had no effect on $\left[\mathrm{Ca}^{2+}\right]_{i}$ while application of $100 \mu \mathrm{M}$ ATP evoked a slight increase in $\left[\mathrm{Ca}^{2+}\right]_{i}$. Overall, 3 of $15 \mathrm{GC}$ positive cells showed small responses to ATP (100-200 $\mu \mathrm{M})$ whereas $\left[\mathrm{Ca}^{2+}\right]_{i}$ was unaffected by ATP in the remaining cells.

\section{ATP-evoked increases in $\left[\mathrm{Ca}^{2+}\right]_{i}$ in astrocytes}

As ATP-evoked increases in $\left[\mathrm{Ca}^{2+}\right]_{i}$ were more prevalent with astrocytes than with either neurons or oligodendrocytes, the focus of the remainder of the present study was on detailed characterization of the responses of astrocytes to ATP. The immunocytochemical results indicated that the level of GFAP expression was typically variable in positive cells (e.g., Fig. 1B); a similar degree of heterogeneity in the expression of GFAP is seen in astrocytes from spinal cord (Fok-Seang and Miller, 1992) and other regions of the CNS (Jensen and Chiu, 1990; McCarthy and Salm, 1991). Also, we found cells that had typical morphological features of astrocytes but in which GFAP expression was not detected.

Therefore, we examined the relationship between effects of 


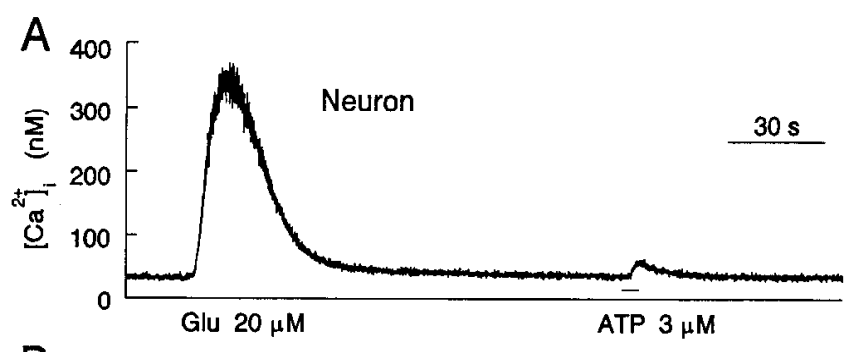

B

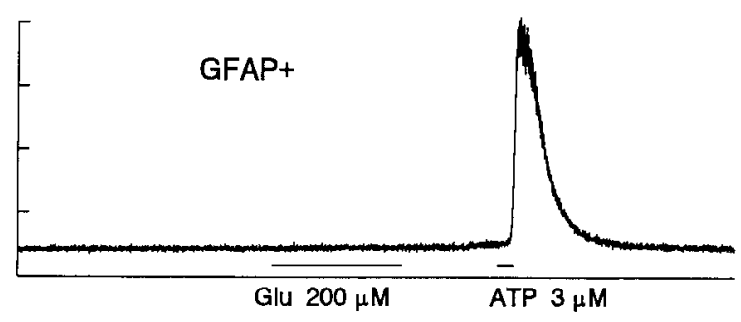

C

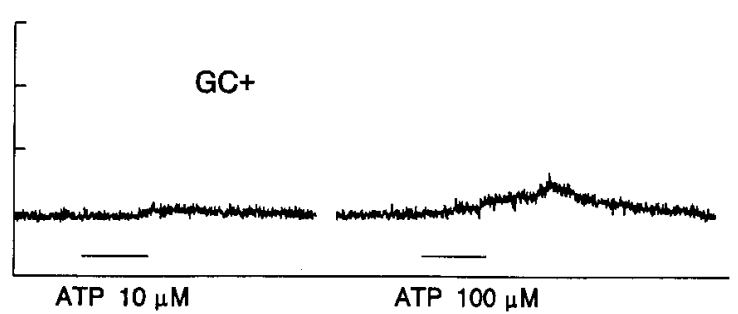

Figure 2. Effects of ATP and glutamate $(\mathrm{Glu})$ on $\left[\mathrm{Ca}^{2+}\right]_{\mathrm{i}}$ in a neuron, astrocyte, and oligodendrocyte. Each trace is a record of $\left[\mathrm{Ca}^{2+}\right]$, from an individual cell. $A$ is from a neuron that responded to glutamate (20 $\mu \mathrm{M}, 2 \mathrm{sec})$ and had a smaller response to ATP ( $3 \mu \mathrm{M}, 5 \mathrm{sec}) . B$ is from a cell that was confirmed after recording as GFAP positive. This astrocyte had no response to glutamate $(200 \mu \mathrm{M}, 40 \mathrm{sec})$ but responded to ATP $(3 \mu \mathrm{M}, 5 \mathrm{sec}) . C$ is from a cell expressing GC. This oligodendrocyte did not respond to $10 \mu \mathrm{M}$ ATP and showed a small response to $100 \mu \mathrm{M}$ ATP. In each record ATP or glutamate was applied during the periods indicated by the horizontal bars below the traces. The time calibration in $A$ applies to all of the records. The gap in the trace in $C$ indicates a 2 min interval between sampling periods.

ATP and expression of GFAP in a series of 30 cells selected on the basis of the morphological characteristics outlined above. ATP (10-25 $\mu \mathrm{M})$ elicited increases in $\left[\mathrm{Ca}^{2+}\right]_{i}$ in all of these cells, and 23 were subsequently found to be GFAP positive. There were no apparent differences in the responses to ATP in GFAPpositive versus GFAP-negative cells. Thus, it appeared that all cells that had morphological features of astrocytes respond to ATP regardless of whether or not expression of GFAP was detected. Importantly, staining for NSE, GC, fibronectin, or B4 lectin was never observed in cells with these morphological characteristics. Therefore, it is possible that such GFAP-negative cells may be astrocytes expressing GFAP at a level below the detection limit of our staining technique or that they may be astrocyte precursors (Fok-Seang and Miller, 1992).

Because of the apparent uniform expression of responses to ATP, morphological criteria were used to select cells for the remainder of the study. In order to test this method of selection, standardized applications of ATP $(3 \mu \mathrm{M}, 10 \mathrm{scc})$ werc made to an additional series of 26 consecutive cells. Each of these cells was found to respond to ATP. Typically $\left[\mathrm{Ca}^{2+}\right]_{i}$ began to increase during the application of ATP, peaked rapidly within $2-5 \mathrm{sec}$, and then returned gradually to baseline levels over the next 20$40 \mathrm{sec}$. In several cells there was a secondary rise in $\left[\mathrm{Ca}^{2+}\right]_{i}$ during the recovery phase. Nevertheless, the increase in $\left[\mathrm{Ca}^{2+}\right]_{i}$

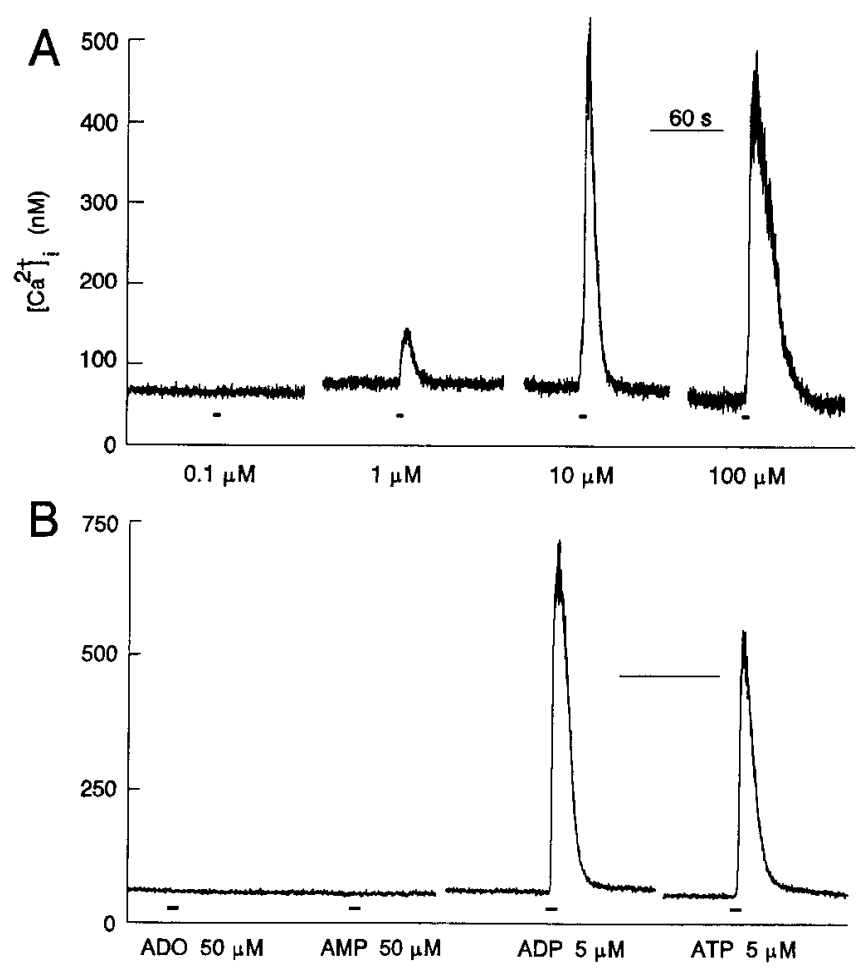

Figure 3. Response to ATP is concentration dependent and is mimicked by ADP but not by AMP or adenosine. $A$, ATP $(5 \mathrm{sec})$ was applied to one cell at concentrations of $0.1,1,10$, and $100 \mu \mathrm{M}$. $B$, In another cell $\left[\mathrm{Ca}^{2+}\right]_{i}$ was unaffected by adenosine $(A D O ; 50 \mu \mathrm{M})$ or $\operatorname{AMP}(50 \mu \mathrm{M})$. In contrast, ADP $(5 \mu \mathrm{M})$ caused a rise in $\left[\mathrm{Ca}^{2+}\right]_{i}$ and the peak of the response was slightly greater than that of the response to ATP $(5 \mu \mathrm{M})$. The gaps in the traces indicate $2 \mathrm{~min}$ intervals between sampling periods. The time calibrations show $60 \mathrm{sec}$ in both records.

evoked by ATP was fully reversible in all cells. The mean $\left[\mathrm{Ca}^{2+}\right]_{i}$ at the peak of the response was $780 \pm 120 \mathrm{~nm}$.

Overall, more than 350 cells were selected in this way and only three did not respond to ATP at concentrations of $25 \mu \mathrm{M}$ or less. While this population was nearly homogeneous in terms of responding to ATP, glutamate $(100-200 \mu \mathrm{M})$ produced small increases in $\left[\mathrm{Ca}^{2+}\right]_{i}$ in only 5 of 27 cells tested, with the remainder being unresponsive.

\section{Increase in $\left[\mathrm{Ca}^{2+}\right]_{\mathrm{i}}$ caused by ATP is concentration dependent}

We found that repeated applications of ATP to an individual cell reproducibly evoked increases in $\left[\mathrm{Ca}^{2+}\right]_{i}$. If a recovery period of about $3 \mathrm{~min}$ or longer was allowed between applications, the peak of the response to 10 or more applications of ATP was stable or showed a gradual $10-15 \%$ decline in amplitude. Thus, to examine the concentration dependence of the response to ATP, repeated applications were made to individual cells at 10 fold increasing concentrations between 0.1 and $100 \mu \mathrm{M}$, allowing at least 3 min intervals between applications. As illustrated in the example in Figure $3 A$, progressively shorter-latency, largeramplitude, and longer-duration responses were evoked by increasing concentrations of ATP. The threshold concentration of ATP was found to be $0.1-1 \mu \mathrm{M}$ and responses were maximum at approximately $10 \mu \mathrm{M}(n=10$ cells $)$.

\section{Effects of other adenine nucleotides and adenosine}

In order to investigate whether the responses to ATP might be mediated by $P_{1}$ or by $P_{2}$ purinergic receptors (Burnstock, 1978), 

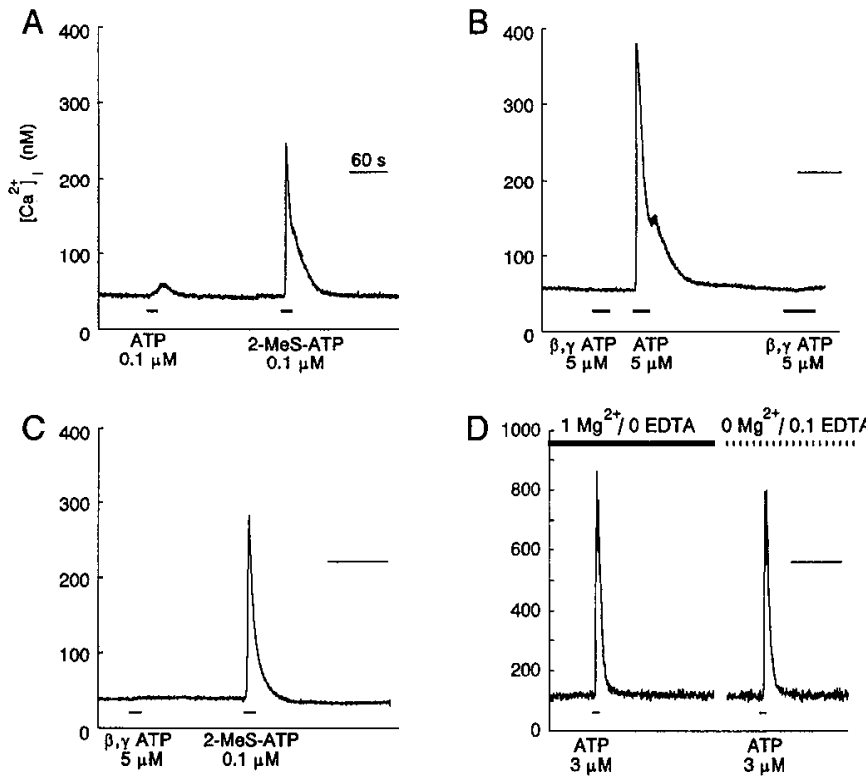

Figure 4. Effects of $\mathrm{P}_{2}$ receptor agonists on $\left[\mathrm{Ca}^{2+}\right]_{i}$. Records of $\left[\mathrm{Ca}^{2+}\right]_{i}$ are shown from four astrocytes. In $A$ 2-methylthio-ATP (2-MeS-ATP; $0.1 \mu \mathrm{M})$ evoked a much larger response than did ATP $(0.1 \mu \mathrm{M})$. The cell shown in $B$ was unaffected by $\beta, \gamma$-methylene-ATP $(\beta, \gamma A T P ; 5 \mu \mathrm{M})$ but responded to ATP $(5 \mu \mathrm{M})$. $C$ illustrates another cell that responded to 2 -methylthio-ATP $(5 \mu \mathrm{M})$ but not to $\beta, \gamma$-methylene-ATP $(5 \mu \mathrm{M})$. On the left in $D$ is shown the response of a cell to ATP $(3 \mu \mathrm{M})$ in the standard extracellular medium, which contained $\mathrm{Mg}^{2+}(1 \mathrm{mM})$. During the 3 min interval indicated by the gap in the record, the bath was exchanged six times with extracellular solution containing no added $\mathrm{Mg}^{2+}$ and containing EDTA $(0.1 \mathrm{~mm})$. ATP was then applied from a second pipette containing the $\mathrm{Mg}^{2+}$-free extracellular solution. The time calibrations are $60 \mathrm{sec}$ in all records.

the effects of adenosine, AMP, and ADP were examined. Adenosine and AMP had no effect on $\left[\mathrm{Ca}^{2+}\right]$, when tested at concentrations up to $100 \mu \mathrm{M}$ whereas ADP produced increases in $\left[\mathrm{Ca}^{2+}\right]_{i}$ that were of equal, or up to $30 \%$ greater, amplitude than those evoked by ATP (Fig. 3B). These results indicate that the response is mediated by $P_{2}$ receptors.

The subtype of $\mathrm{P}_{2}$ receptor was investigated using $\beta, \gamma$-methylene-ATP and 2-methylthio-ATP, which have been reported to be selective agonists for $P_{2 X}$ and $P_{2 Y}$ subtypes, respectively (Burnstock and Kennedy, 1985; Cusack and Hourani, 1990). As shown for the cell in Figure 4A,2-methylthio-ATP at a concentration of $0.1 \mu \mathrm{M}$ produced a much larger increase in $\left[\mathrm{Ca}^{2+}\right]_{i}$ than did $0.1 \mu \mathrm{M}$ ATP, suggesting that 2-methylthio-ATP is more potent than ATP. Also, $\beta, \gamma$-methylene-ATP $(1-50 \mu \mathrm{M})$ had no effect on $\left[\mathrm{Ca}^{2+}\right]_{i}$ (Fig. $\left.4 B\right)$ in any cells $(n=8)$, even those that exhibited a large response to $0.1 \mu \mathrm{M} 2$-methylthio-ATP(Fig. $4 C$ ).

It has heen reported that $\mathrm{Mg}$-ATP may be required to mediate responses to ATP in cardiac muscle (Christie et al., 1992). We examined the requirement for Mg-ATP by testing ATP $(3 \mu \mathrm{M})$ in extracellular solution containing no added $\mathrm{Mg}$ and EDTA $(100 \mu \mathrm{M})$. For each cell tested $(n=6)$, the increase in $\left[\mathrm{Ca}^{2+}\right]_{i}$ evoked by ATP in media containing $\mathrm{Mg}^{2+}$ was similar in amplitude to that evoked in $\mathrm{Mg}^{2+}$-free solution, indicating that Mg-ATP is not required (Fig. $4 D$ ).

Suramin blocks ATP-evoked increase in $\left[\mathrm{Ca}^{2+}\right]_{\mathrm{i}}$

Suramin, a trypanocidal drug, is a competitive antagonist at $\mathrm{P}_{2 \mathrm{x}}$ and $P_{2 Y}$ receptors (Dunn and Blakeley, 1988; Hoiting et al.,
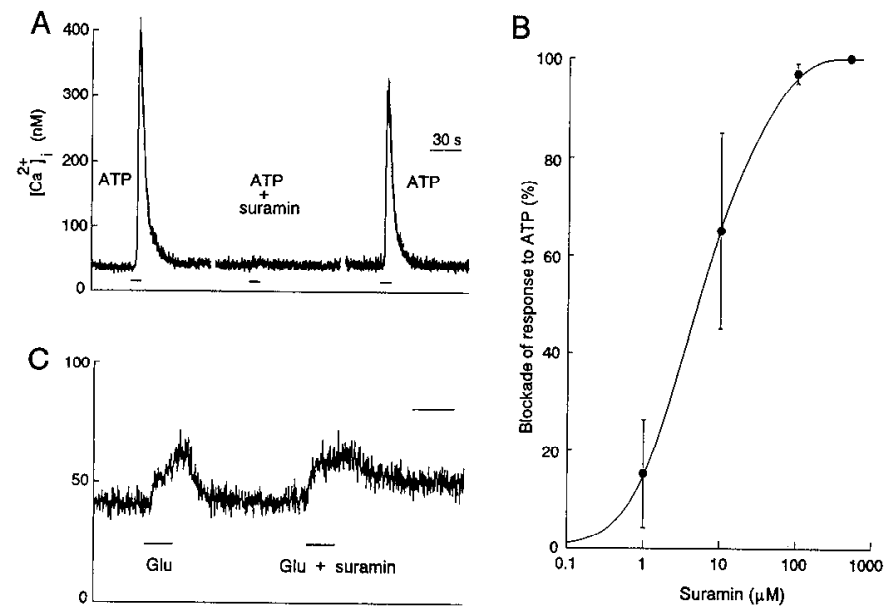

Figure 5. Suramin causes a reversible, dose-dependent blockade of the response to ATP. $A$ shows $\left[\mathrm{Ca}^{2+}\right]$ recorded in an astrocyte. The increase in $\left[\mathrm{Ca}^{2+}\right]_{i}$ caused by ATP $(3 \mu \mathrm{M})$ is shown on the left. The bathing solution was then replaced with one containing suramin $(100 \mu \mathrm{M})$. The cell did not respond to $3 \mu \mathrm{M}$ ATP applied from a pipette also containing $100 \mu \mathrm{M}$ suramin. The control bathing solution was then returned, and the response to $\operatorname{ATP}(3 \mu \mathrm{M})$ is shown on the right. The gaps in the record indicate 2 min intervals between sampling periods. In the graph in $B$ the mean percentage blockade of the response to ATP is plotted versus suramin concentration (error bars show SEM). Data are from five astrocytes at suramin concentrations greater than $0.1 \mu \mathrm{M}$; three cells were tested at this concentration. The smooth curve shows the logistic function best fitted to the means; the equation for this curve is $102 /(1+(x)$ $\left.5.6)^{1.02}\right)-0.1$. $C$ shows a continuous record of $\left[\mathrm{Ca}^{3+}\right]$, from an astrocyte that responded to L-glutamate $(100 \mu \mathrm{M})$. The bath solution was exchanged with one containing $500 \mu \mathrm{M}$ suramin. L-Glutamate $(100 \mu \mathrm{M})$ was applied again from a pipette that also contained suramin.

1990; Inoue et al., 1991). As illustrated in Figure $5 A$, suramin at a concentration of $100 \mu \mathrm{M}$ caused a complete and reversible blockade of the response to ATP ( $n=8$ cells). The blockade of ATP-evoked responses by suramin was concentration dependent (Fig. $5 B$ ). The smooth curve in Figure $5 B$ shows that the concentration dependence of the blockade was well fit by the logistic function. The concentration of suramin calculated to produce $50 \%$ inhibition of the responses $\left(\mathrm{IC}_{50}\right)$ was $5.6 \pm 2.5$ $\mu \mathrm{M}$. The effect of suramin was not nonselective becausc at a concentration of $500 \mu \mathrm{M}$ suramin failed to block glutamateevoked increases in $\left[\mathrm{Ca}^{2+}\right]_{i}$ in sensitive astrocytes (Fig. $5 \mathrm{C}$ ) or in neurons $(n=5)$.

\section{Lack of dependence upon extracellular $\mathrm{Ca}^{2+}$}

In order to determine whether the increase in $\left[\mathrm{Ca}^{2+}\right]_{i}$ produced by ATP resulted from influx of $\mathrm{Ca}^{2}$ । or release of $\mathrm{Ca}^{2+}$ from intracellular stores, responses to ATP were compared before versus after removing extracellular $\mathrm{Ca}^{2+}$. A representative experiment is shown in Figure 6. Two control responses to ATP $(4 \mu \mathrm{M})$ were elicited in medium containing $1.3 \mathrm{mM} \mathrm{Ca}^{2+}$. The bathing solution was then replaced by one with no added $\mathrm{Ca}^{2+}$ and containing $100 \mu \mathrm{M}$ EGTA, and 2 min later ATP produced an increase in $\left[\mathrm{Ca}^{2+}\right]_{i}$ similar to that seen in the control responses. The response to ATP persisted, but was dramatically reduced in amplitude after $17 \mathrm{~min}$ exposure to $\mathrm{Ca}^{2+}$-free media, possibly due to depletion of intracellular $\mathrm{Ca}^{2+}$ stores. The response returned to about $70 \%$ of the control level after medium containing $\mathrm{Ca}^{2+}$ was reintroduced. Responses to ATP after removing extracellular $\mathrm{Ca}^{2+}$ were observed in all cells tested $(n=$ 


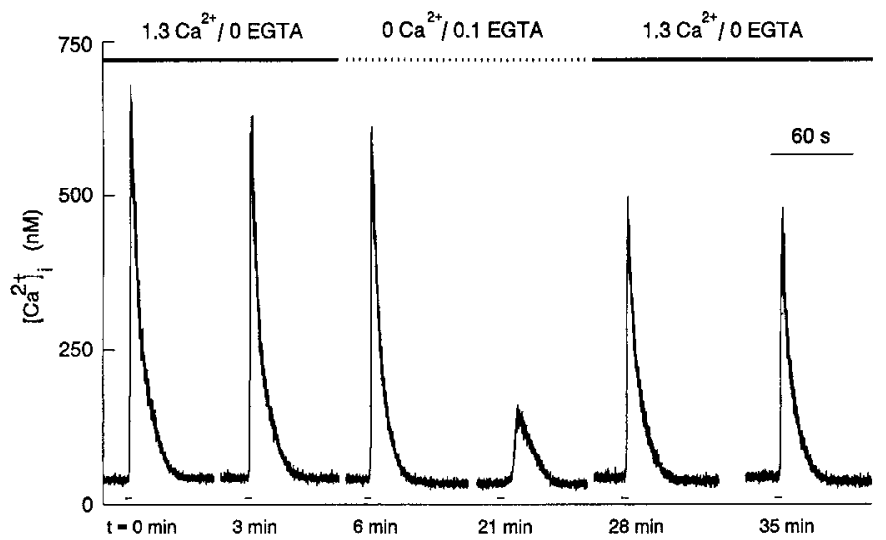

Figure 6. Extracellular $\mathrm{Ca}^{2+}$ is not required for ATP-evoked increase in $\left[\mathrm{Ca}^{2+}\right]_{i}$. The traces show $\left[\mathrm{Ca}^{2+}\right]_{i}$ measured in an individual astrocyte at time $(t)$ indicated below each section of record. The gaps in the record indicate periods when $\left[\mathrm{Ca}^{2+}\right]$, was not sampled, and the horizontal bars below the record illustrate periods when ATP $(4 \mu \mathrm{M})$ was applied. Two applications of ATP were made in control extracellular solution that contained $1.3 \mathrm{mM} \mathrm{Ca}^{2+}$. After the second application, at $t=4 \mathrm{~min}$, the bath was exchanged with extracellular solution containing no added $\mathrm{Ca}^{2+}$ and $0.1 \mathrm{~mm}$ EGTA. Subsequently ATP was applied twice from a second pipette in which ATP was dissolved in the $\mathrm{Ca}^{2+}$-free extracellular solution. At $t=23 \mathrm{~min}$ the bath volume was replaced with 'control extracellular solution and ATP, in the control solution, was then applied as indicated.

10). In some cases the first application of ATP in the $\mathrm{Ca}^{2+}$-free media was made more than $5 \mathrm{~min}$ after exchanging the solutions and this response was found to be much smaller than the control responses.

These observations suggest that the ATP-evoked increase in $\left[\mathrm{Ca}^{2+}\right]_{j}$ is not dependent upon extracellular $\mathrm{Ca}^{2+}$ and therefore likely results from release of $\mathrm{Ca}^{2+}$ from intracellular stores. To investigate further the possibility that ATP might cause influx of $\mathrm{Ca}^{2+}$, we examined the effects of the divalent cations $\mathrm{Cd}^{2+}$ and $\mathrm{Mn}^{2+} \cdot \mathrm{Cd}^{2+}$ blocks influx of $\mathrm{Ca}^{2+}$ particularly through voltage-gated channels (Tsien et al., 1988). It was found that $\mathrm{Cd}^{2+}$ $(100 \mu \mathrm{M})$ did not affect the increase in $\left[\mathrm{Ca}^{2+}\right]_{i}$ evoked by ATP (Fig. $7 A ; n=5$ cells). $\mathrm{Mn}^{2+}$ permeates many types of $\mathrm{Ca}^{2+}$ permeable channels, and it has the additional property of quenching the fura-2 fluorescent signal (Grynkiewicz et al., 1985). Thus, $\mathrm{Mn}^{2+}$ was used to probe for influx of divalent cations. ATP was applied in the presence of $\mathrm{Mn}^{2+}(1 \mathrm{mM})$ in the extracellular medium while the level of fura-2 fluorescence was measured by averaging the signals recorded at 340 and $380 \mathrm{~nm}$ excitation wavelengths. As shown on the left in Figure $7 B$, the $340+380$ average signal remained relatively constant despite a large increase in $\left[\mathrm{Ca}^{2+}\right]_{i}$ evoked by ATP. In the presence of extracellular $\mathrm{Mn}^{2+}(1 \mathrm{mM})$, ATP still increased $\left[\mathrm{Ca}^{2+}\right]_{i}$ and there was no decline in the mean $340+380$ signal, indicating that there was no influx of $\mathrm{Mn}^{2+}$. To confirm that $\mathrm{Mn}^{2+}$ influx could be detected, it was applied along with glutamate onto neurons. Glutamate is known to cause influx of $\mathrm{Ca}^{2+}$ into neurons (Mayer and Westbrook, 1987), and when glutamate was applied with $\mathrm{Mn}^{2+}$ there was a marked decline in the average $340+380$ signal (Fig. 7C).

\section{Caffeine fails to affect responses to $A T P$}

To investigate the intracellular pool of $\mathrm{Ca}^{2+}$ responsible for the response to ATP, we examined the effects of caffeine, which at concentrations of $1 \mathrm{~mm}$ or greater releases $\mathrm{Ca}^{2+}$ from the ryanodine/caffeine-sensitive intracellular pool (Miller, 1991). As shown in the example in Figure $8 A$, applying caffeine at a concentration of $10 \mathrm{~mm}$ evoked large increases in $\left[\mathrm{Ca}^{2+}\right]_{i}$ in all neurons tested $(n=8)$. On the other hand, caffeine did not increase $\left[\mathrm{Ca}^{2+}\right]_{i}$ in astrocytes (Fig. $8 B, C ; n=17$ ) and in fact in six cases caffeine caused a slight decrease in $\left[\mathrm{Ca}^{2+}\right]_{i}$. Furthermore, Figure $8 B$ illustrates that applying caffeine just prior to ATP did not prevent the response to ATP. In addition, caffeine did not increase $\left[\mathrm{Ca}^{2+}\right]_{i}$ when applied just after recovery from
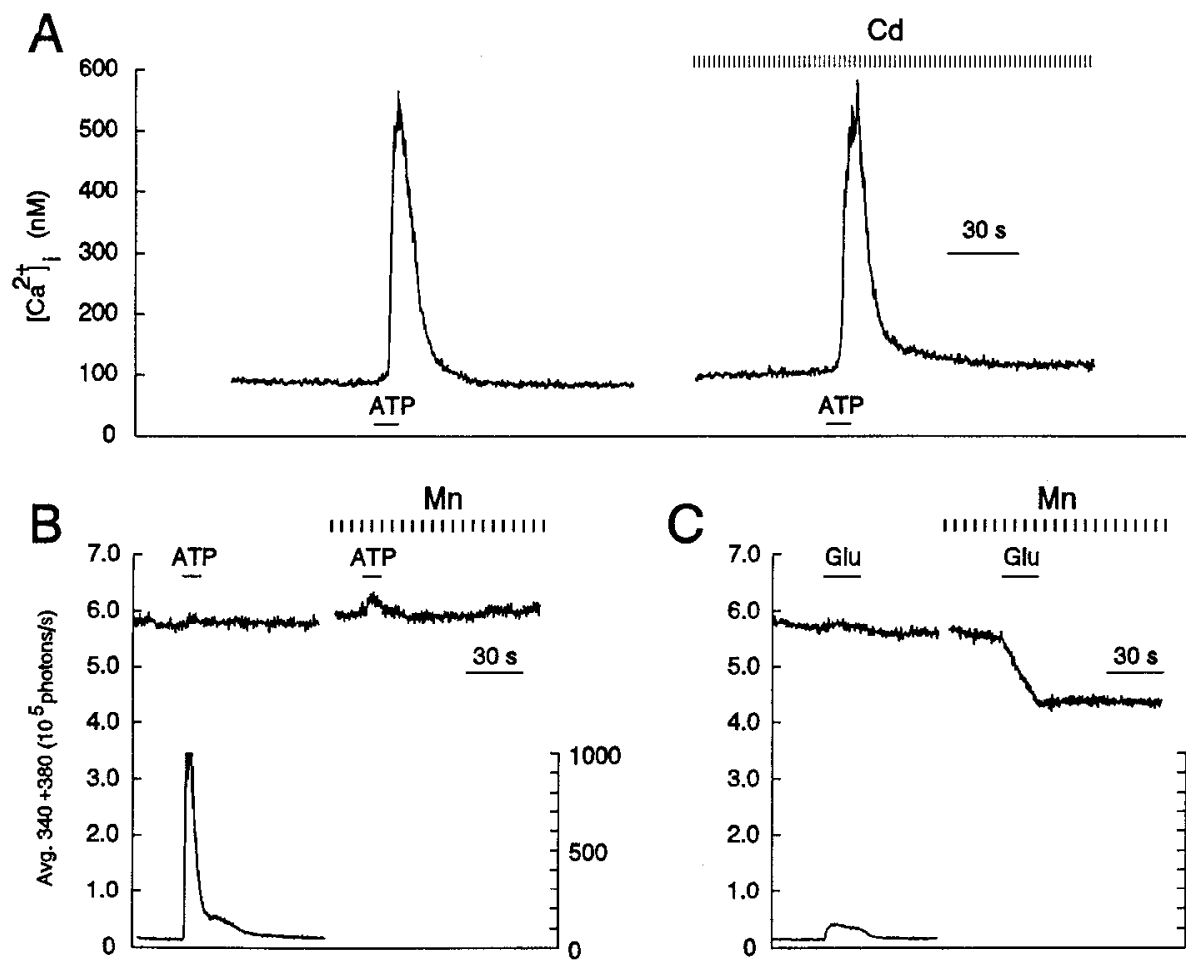

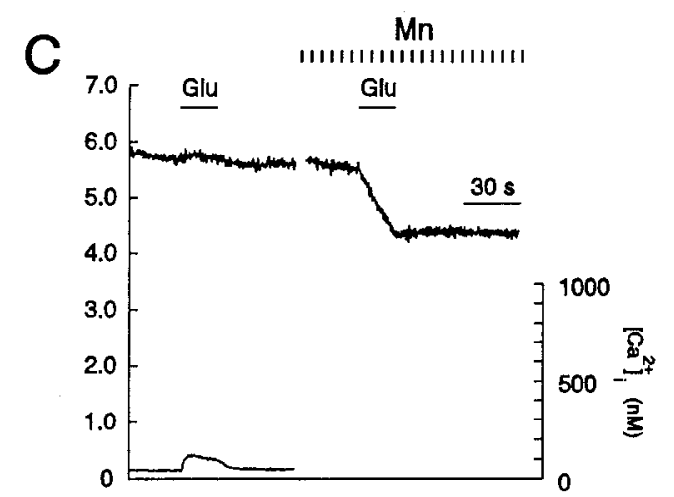

Figure 7. $\mathrm{Cd}^{2+}$ and $\mathrm{Mn}^{2+}$ do not affect responses to ATP. $A$ illustrates $\left[\mathrm{Ca}^{2+}\right]_{i}$ recorded in an astrocyte, and the horizontal bars below the record indicate applications of ATP $(3 \mu \mathrm{M})$. A control response to ATP is shown on the left, and the response when $\mathrm{Cd}^{2+}(100 \mu \mathrm{M})$ had been added to the extracellular solution, indicated by the hatched bar above the record, is shown on the right. In $B$ and $C$ the average of the $340+380$ $\mathrm{nm}$ photon counts is plotted in the $u p$ per records and $\left[\mathrm{Ca}^{2+}\right]_{i}$ is shown in the lower records; $B$ is from another astrocyte and $C$ is from a neuron. In $B$ the solid bars above the upper records indicate applications of ATP ( $3 \mu \mathrm{M})$ and in $C$ the solid bars show applications of L-glutamate $(10 \mu \mathrm{M})$. The hatched bars above the records in $B$ and $C$ indicate that $\mathrm{Mn}^{2+}(\mathrm{l} \mathrm{mM})$ had been added to the extracellular solution. Note that $\left[\mathrm{Ca}^{2+}\right]_{i}$ was not calculated when $\mathrm{Mn}^{2+}$ was present. The gaps in the records in $A-C$ indicate 2 min intervals between $\left[\mathrm{Ca}^{2+}\right]_{i}$ measurements. 

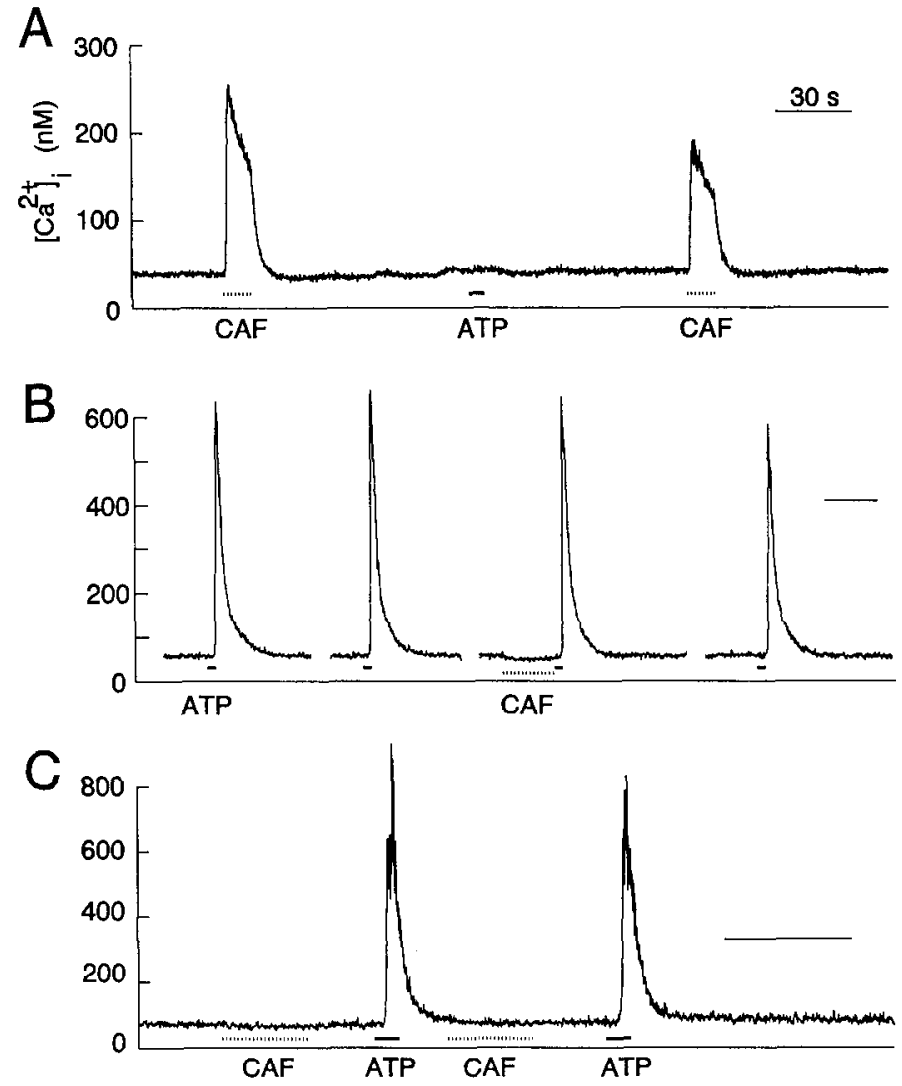

Figure 8. Caffeine does not affect ATP-evoked increase in $\left[\mathrm{Ca}^{2+}\right]_{i} . A$, A continuous record of $\left[\mathrm{Ca}^{2+}\right]$, from a dorsal horn neuron is shown. Caffeine $(C A F ; 10 \mathrm{~mm})$, applied during periods indicated by the hatched bars below the record, caused a rise in $\left[\mathrm{Ca}^{2+}\right]_{i}$. On the other hand, ATP $(3 \mu \mathrm{M})$ had no effect on this cell. $B$ and $C$ are records of $\left[\mathrm{Ca}^{2+}\right]$ from two astrocytes. In $B$ ATP was tested twice before applying caffeine; the third application of ATP was immediately preceded by applying caffeine. Caffeine caused a small decrease in the level of $\left[\mathrm{Ca}^{2+}\right]_{i}$ but had no effect on the response to ATP. For the cell in $C$, caffeine had no effect on $\left[\mathrm{Ca}^{2+}\right]_{i}$ either before or after applying ATP. The gaps in the records $B$ indicate 2 min intervals in the sampling. All time calibrations show $30 \mathrm{sec}$.

ATP (Fig. 8C), indicating the ATP-evoked increase in $\left[\mathrm{Ca}^{2+}\right]$ did not lead to loading of a caffeine-sensilive pool.

\section{Thapsigargin blocks increase in $\left[\mathrm{Ca}^{2+}\right]_{\mathrm{i}}$ evoked by ATP}

The intracellular pool of $\mathrm{Ca}^{2+}$ was further examined by the use of thapsigargin, a sesquiterpene lactone, which has been reported to be a highly selective and potent inhibitor of endoplasmic reticulum $\mathrm{Ca}^{2+}$ ATPases (Thastrup, 1990). Thapsigargin thereby depletes specific endoplasmic reticulum pools of $\mathrm{Ca}^{2+}$. We found that thapsigargin $(1 \mu \mathrm{M})$ had no effect on basal levels of $\left[\mathrm{Ca}^{2+}\right]_{i}$ in any of the cells tested $(n-11)$. As illustrated in Figure 9, immediately after a $2 \mathrm{~min}$ application of thapsigargin the response to ATP had decreased to $20 \%$ of the control level. By 5 min after applying thapsigargin ATP did not evoke any change in $\left[\mathrm{Ca}^{2+}\right]_{i}$. However, by $60 \mathrm{~min}$ after applying thapsigargin the response to ATP had recovered partially to $35 \%$ of control. Thapsigargin blocked the ATP-evoked increase in $\left[\mathrm{Ca}^{2+}\right]_{i}$ in all cells tested.

\section{Responses to ATP during patch-clamp recording}

Patch-clamp recordings were made from astrocytes selected on the basis of the morphological features outlined above. The

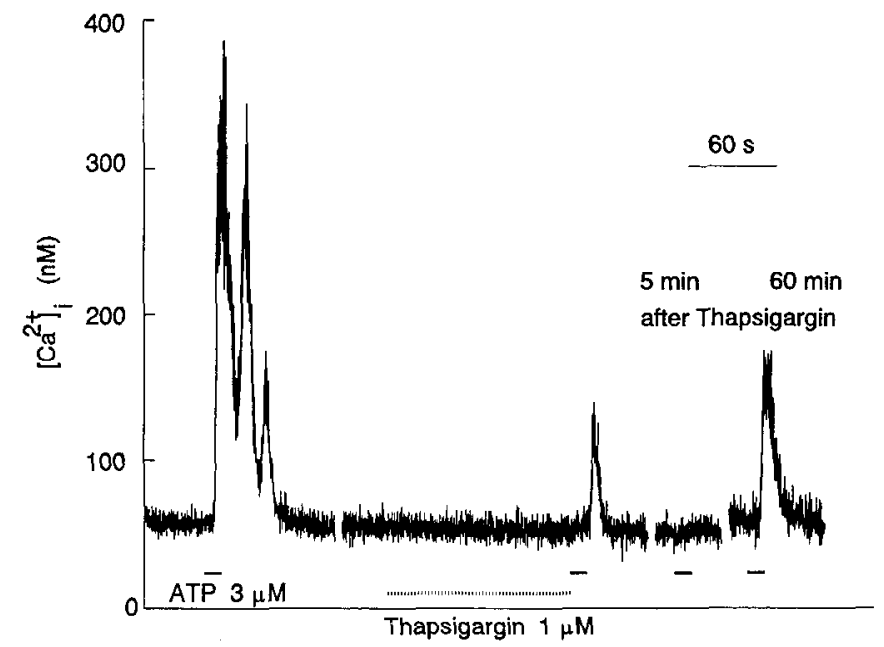

Figure 9. Thapsigargin causes a long-lasting blockade of the response to ATP. A control response to ATP ( $3 \mu \mathbf{M}$; solid bars below record) is shown on the left. After a 2 min interval, thapsigargin $(1 \mu \mathrm{M})$ was applied via a pipette for the period indicated by the hatched bar. ATP was applied immediately after ending the thapsigargin application and the response to ATP was greatly diminished. Two more applications of ATP were made, 5 and $60 \mathrm{~min}$ after thapsigargin.

recordings were readily made when the patch pipette was placed on the cell membrane near the nucleus and no attempt was made to record from cell processes. To try to minimize problems inherent in attempting to voltage-clamp cells with extensive processes, we avoided cells more than about $75 \mu \mathrm{M}$ across and applied ATP directly onto the region near the nucleus where control of membrane potential would be expected to be the best. Input resistance of the cells studied was found to be in the range of 100-300 Ms.

Intracellular $\left[\mathrm{Ca}^{2+}\right]$ measurements and perforated-patch recordings were made simultaneously so that responses to ATP could be studied in cells where the intracellular milieu was minimally altered. An example of recordings from a cell using the perforated-patch technique is shown in Figure 10 $\mathrm{A}$. The records on the left were taken 5 min after the perforation had stabilized. The increase in $\left[\mathrm{Ca}^{2+}\right]_{i}$ evoked by ATP $(20 \mu \mathrm{M})$ was associated with a small outward membrane current when the membrane potential was held at $-60 \mathrm{mV}$. Thus, the increase in $\left[\mathrm{Ca}^{2+}\right.$, evoked by ATP was independent of any change in membrane potential. After switching to current-clamp recording ATP was applied again and caused hyperpolarization (Fig. 10A, right). Approximately 5 min after this application there was a sudden decrease in the baseline level of $\left[\mathrm{Ca}^{2+}\right]_{i}$, indicating that the patch had ruptured and the pipette solution, containing $11 \mathrm{~mm}$ EGTA, had entered the cell. ATP was applied 3 min later and did not cause either the increase $\left[\mathrm{Ca}^{2+}\right]_{i}$ or the membrane current response, likely as a result of $\mathrm{Ca}^{2+}$ buffering by EGTA. The loss of responsiveness was not likely due to deterioration of the cell,

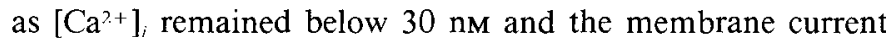
was stable for more than $20 \mathrm{~min}$ after rupture of the patch.

During whole-cell recordings when the intracellular solution contained only $100 \mu \mathrm{M}$ EGTA, baseline levels of $\left[\mathrm{Ca}^{2+}\right]_{i}$ were maintained in the normal range and responses to ATP were evoked for up to $30 \mathrm{~min}$. For the cell shown in Figure $10 B$, ATP $(20 \mu \mathrm{M}, 30 \mathrm{sec})$ caused an outward current the time course of which paralleled that of the increase in $\left[\mathrm{Ca}^{2+}\right]_{i}$. Note that the current evoked by ATP developed after the increase in $\left[\mathrm{Ca}^{2+}\right]_{i}$ had begun. 

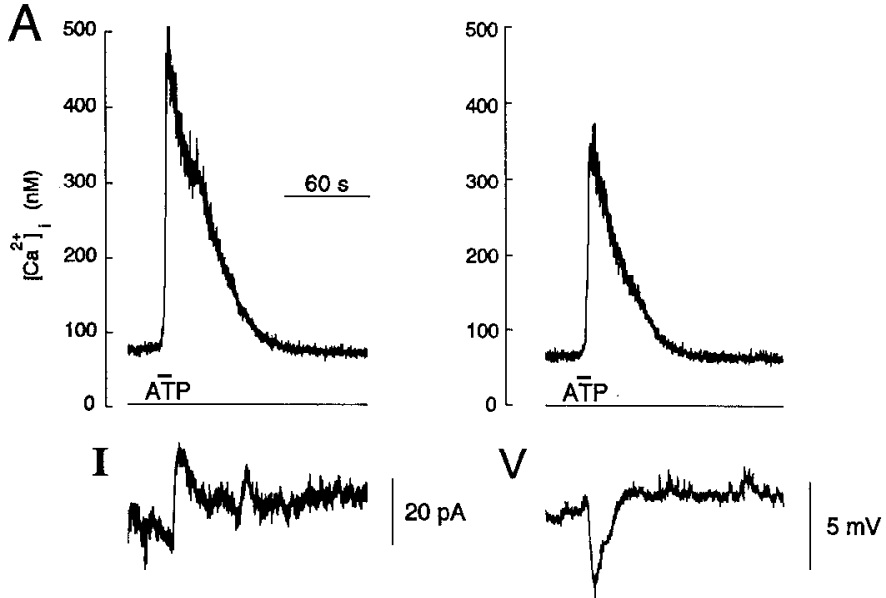

Nystatin Patch Recording

B

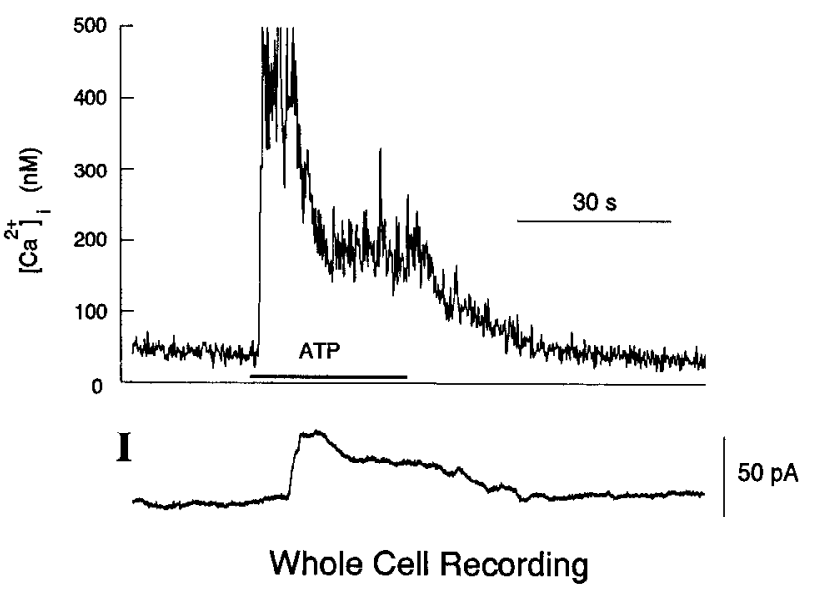

Figure 10. Effects of ATP during simultaneous optical and electrophysiological recording from two astrocytes. $A$, Records of $\left[\mathrm{Ca}^{2+}\right]_{i}$ are shown in the top panels. The lower traces show corresponding records membrane current $(I)$ or voltage $(V)$ on the left and right, respectively. The recordings were made after a stable perforation had developed during nystatin-patch recording as described in Results. ATP $(25 \mu \mathrm{M})$ was applied as indicated by the horizontal bars below the records of $\left[\mathrm{Ca}^{2+}{ }^{2}\right.$. The time calibration applies to all records. $B$ shows simultaneously acquired records of $\left[\mathrm{Ca}^{2+}\right]_{i}$ and membrane current obtained during recording in the whole-cell configuration from a different astrocyte. In this case a long application of ATP $(25 \mu \mathrm{M})$ was made.

While ATP consistently produced increases in $\left[\mathrm{Ca}^{2+}\right]_{i}$, there was considerable cell-to-cell variability in the currents evoked by ATP. This variability is illustrated in the examples in Figure 11, which shows outward (Fig. 11 $A$ ), inward (Fig. 11B), and mixed (Fig. $11 C, D$ ) currents caused by ATP. Overall, ATP evoked an outward current in 14 cells, an inward current in 11 cells, and mixed currents with inward and outward components in the remaining cells. We observed that the currents evoked by ATP were typically not stable and appeared to wash out in all cells studicd using the whole-cell configuration. Measurements of membrane conductance during responses to ATP were attempted in 12 cells. ATP-evoked conductance increases were found in six cells but in the remaining cells no change in conductance was detected. Due to the variability and the washout of the currents evoked by ATP, detailed characterization of them was not attempted in this study.
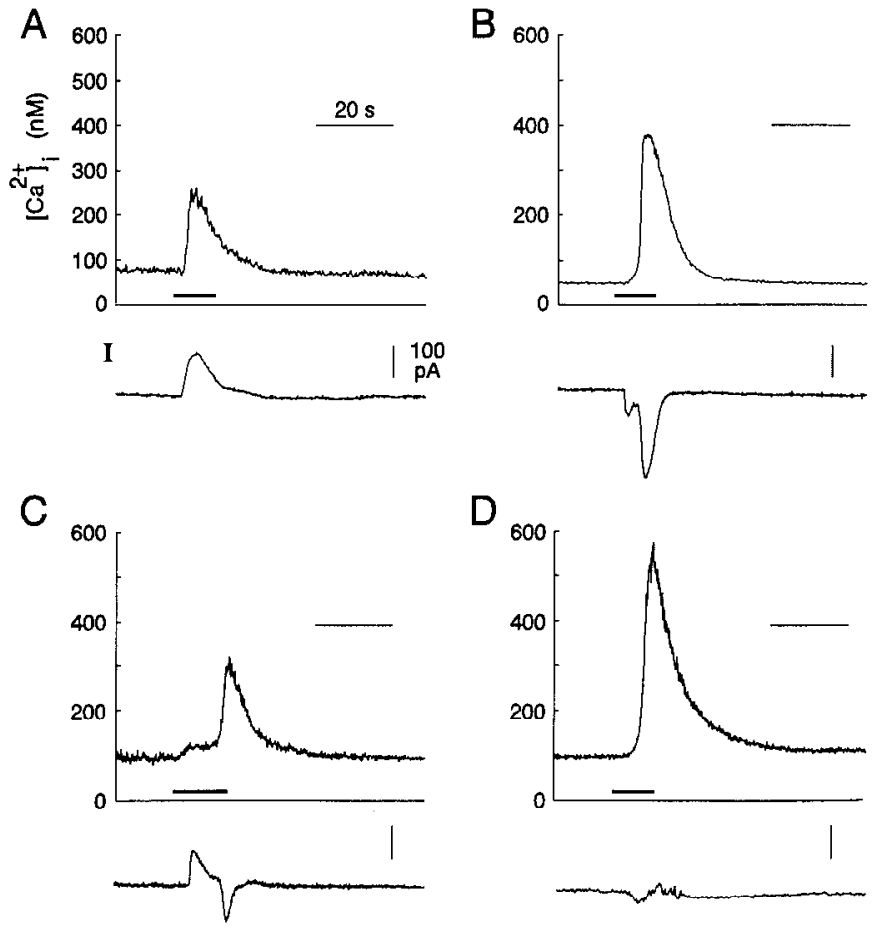

Figure 11. Diversity of membrane currents produced by applying ATP to astrocytes. The upper and lower traces in each panel show simultaneously acquired records of $\left[\mathrm{Ca}^{2+}\right]_{i}$ and whole-cell membrane current, respectively, from four individual astrocytes. ATP $(3 \mu \mathrm{M}$; horizontal bar below traces) increased $\left[\mathrm{Ca}^{2+}\right]_{i}$ in all of the cells, but membrane currents evoked by ATP were distinct in each cell. Calibration is $20 \mathrm{sec}, 100 \mathrm{pA}$ in cach pancl.

\section{Discussion}

In this study we show that ATP increases $\left[\mathrm{Ca}^{2+}\right]_{i}$ in neurons, astrocytes, and oligodendrocytes in mixed cultures of dorsal spinal cord. Nearly all of the astrocytes responded to ATP, and therefore, the main focus of the present investigation has been to characterize these responses in detail.

\section{ATP activates $P_{2 Y}$ receptors, leading to release of intracellular $\mathrm{Ca}^{2+}$ in astrocytes}

The ATP-evoked increases in $\left[\mathrm{Ca}^{2+}\right]_{i}$ were dependent upon ATP concentration and were mimicked by ADP but not by AMP or adenosine, indicating that the responses were mediated by $P_{2}$ rather than by $P_{1}$ purinergic receptors. 2-Methylthio-ATP, a selective $P_{2 Y}$ agonist, was more potent than was ATP itself whereas $\beta, \gamma$-methylene-ATP, a selective $\mathrm{P}_{2 \mathrm{x}}$ agonist, had no effect even at concentrations 50 -fold greater than those of 2 -methylthio-ATP. Therefore, the apparent rank order of agonist potency was 2 -methylthio-ATP $>\mathrm{ATP} \approx \mathrm{ADP} \gg \beta, \gamma$ methylene-ATP $=$ AMP $=$ adenosine. These findings suggest that the increases in $\left[\mathrm{Ca}^{2+}\right]$, were mediated via the $\mathrm{P}_{2 \mathrm{Y}}$ subtype of receptor.

Our results indicate that the receptor mediating the ATPevoked responses in astrocytes is pharmacologically distinct from other $P_{2}$ receptor subtypes, $P_{2 U}, P_{2 T}$, or $P_{2 Z}$ receptors. $P_{2 U}$ receptors have been implicated in ATP-evoked increases in $\left[\mathrm{Ca}^{2+}\right]_{\text {, }}$ in fibroblasts, neutrophils, HL60 cells, and Erlich tumor cells (O'Connor et al., 1991). However, 2-methylthio-ATP is only a partial agonist at $P_{2 U}$ receptors and is much less potent than is 
ATP. Thus, $P_{2 U}$ receptors do not appear to mediate the responses of astrocytes to ATP. $P_{2 T}$ and $P_{2 Z}$ receptors have been described only in platelets (Gordon, 1986) and immune cells (Cockcroft and Gomperts, 1980), respectively. ADP is the preferred ligand at $\mathrm{P}_{2 \mathrm{~T}}$ receptors whereas $\mathrm{ATP}$ is an antagonist at these receptors. At $\mathbf{P}_{2 Z}$ receptors 2 -methylthio-ATP is no more potent than is ATP itself (Tatham et al., 1988) and ADP is inactive (Cusack and Hourani, 1990). Thus, neither $P_{2 T}$ nor $P_{2 Z}$ receptors appear to be involved in the responses of astrocytes.

We found that suramin caused a concentration-dependent and reversible inhibition of ATP-evoked increases in $\left[\mathrm{Ca}^{2+}\right]_{i}$. At concentrations of $100 \mu \mathrm{M}$ or greater suramin completely blocked the responses to ATP indicating that they are mediated entirely via suramin-sensitive receptors. The $\mathrm{IC}_{50}$ for suramin was about $6 \mu \mathrm{M}$, which is less than the value of approximately $30 \mu \mathrm{M}$ observed for blockade of $\mathrm{P}_{2 Y}$-mediated responses in the guinea pig taenia caeci (Den Herlog et al., 1989) and in PC12 cells (Inoue et al., 1991). Previous studies have indicated that suramin is quite selective in blocking $P_{2}$ purinergic receptors in a number of systems: it has no effect on responses mediated by $\alpha$-adrenergic receptors in the taenia caeci (Den Hertog et al., 1989), by muscarinic receptors in the taenia coli (Hoyle et al., 1990) or in the vas deferens (Dunn and Blakeley, 1988), by nicotinic receptors in PC12 cells (Inoue et al., 1991), or by neuropeptide $\mathrm{Y}$ receptors in the vasculature (Urbanek et al., 1990). In the present study we found that suramin did not inhibit $\mathrm{Ca}^{2+}$ responses to glutamate in astrocytes or in neurons. From these results we suggest that suramin might be a selective, competitive antagonist of $\mathrm{P}_{2 \mathrm{Y}}$-mediated increases in $\left[\mathrm{Ca}^{2+}\right]_{i}$ in astrocytes.

A possible alternative mechanism for the ATP-evoked increase in $\left[\mathrm{Ca}^{2+}\right]_{i}$ is that ATP was a substrate for an ectoprotein kinase (Ehrlich et al., 1986). Ectoprotein kinase activity is expressed by a number of cell types including astrocytes (Agren and Ronquist, 1974). In ventricular myocytes (Christie et al., 1992) and in vas deferens smooth muscle (Fedan and Lamport, 1990; Lamport-Vrana et al., 1991) increases in $\left[\mathrm{Ca}^{2+}\right]_{i}$ produced by ATP appear to be the result of phosphorylation of the extracellular domain of membrane protein(s) by an ectoprotein kinase. Thus, it may seem possible that the $\mathrm{P}_{2 Y}$ "receptors" causing the presently observed effects of ATP might in fact be ectoprotein kinase(s). However, the responses to ATP were evoked in the absence of $\mathrm{Mg}^{2+}$, which is absolutely required for kinase activity, and were also elicited by ADP. Thus, ectoprotein kinase does not appear to mediate the increase in $\left[\mathrm{Ca}^{2+}\right]_{i}$.

The ATP-evoked increases in $\left[\mathrm{Ca}^{2+}\right]_{i}$ resulted from release of stored intracellular $\mathrm{Ca}^{2+}$, as they persisted in media with no added $\mathrm{Ca}^{2+}$ and containing $0.1 \mathrm{~mm}$ EGTA. Previous biochemical studies have reported that ATP-evoked increases in $\left[\mathrm{Ca}^{2+}\right]_{i}$ in cortical astrocytes are correlated with increases in inositol trisphosphate $\left(\mathrm{IP}_{3}\right)$ levels caused by ATP (Pearce et al., 1989) or by 2-methylthio-ATP (Kastritsis et al., 1992), indirectly implicating $\mathrm{IP}_{3}$ as the second messenger mediating ATP-evoked release of intracellular $\mathrm{Ca}^{2+}$. Elsewhere we provide direct evidence, using simultaneous measurement of $\left[\mathrm{Ca}^{2+}\right]_{i}$ and wholecell recording, that $\mathrm{IP}_{3}$ mediates the increase in $\left[\mathrm{Ca}^{2+}\right]_{i}$ caused by ATP in astrocytes from the dorsal spinal cord (Salter and Hicks, 1992).

Influx of $\mathrm{Ca}^{2+}$ through voltage-insensitive channels has been reported to follow release of intracellular $\mathrm{Ca}^{2+}$ from $\mathrm{IP}_{3}$-sensitive stores (Berridge, 1993). In the present study we could find no direct evidence for influx of $\mathrm{Ca}^{2+}$ : neither removal of extra- cellular $\mathrm{Ca}^{2+}$ nor addition of $\mathrm{Cd}^{2+}$ blocked the increase in $\left[\mathrm{Ca}^{2+}\right]_{i}$ evoked by ATP, and ATP did not appear to cause influx of $\mathrm{Mn}^{2+}$. Thus, it is possible that release of intracellular $\mathrm{Ca}^{2+}$ by ATP does not lead to influx in these astrocytes. On the other hand, influx might not have been detected in the present experiments if the increase in $\left[\mathrm{Ca}^{2+}\right]_{i}$ resulting from the influx was very small relative to that caused by release and if the influx channels were not blocked by $\mathrm{Cd}^{2+}$ or were impermeable to $\mathrm{Mn}^{2+}$ (Meldolesi et al., 1991).

In studies on purificd cortical astrocytes it has been reported that ATP causes influx of $\mathrm{Ca}^{2+}$ (Neary et al., 1988, 1991; Kastritsis et al., 1992). However, adenosine also produces $\mathrm{Ca}^{2+}$ influx into these astrocytes (Neary et al., 1988). Thus, as cortical astrocytes are capable of forming adenosine from ATP extracellularly (Lai and Wong, 1991), it is possible that administering ATP to these cells results in influx of $\mathrm{Ca}^{2+}$ that is in fact caused by adenosine.

\section{ATP causes release of $\mathrm{Ca}^{2+}$ from an intracellular pool that is thapsigargin sensitive and caffeine insensitive}

We observed that caffeine did not increase baseline $\left[\mathrm{Ca}^{2+}\right]_{i}$, indicating that the astrocytes do not have caffeine-sensitive stores that contain $\mathrm{Ca}^{2+}$ prior to stimulation with ATP. Furthermore, caffeine did not affect $\left[\mathrm{Ca}^{2+}\right]_{i}$ when applied immediately after the ATP-evoked increase in $\left[\mathrm{Ca}^{2+}\right]_{i}$, suggesting that raising intracellular $\mathrm{Ca}^{2+}$ levels did not lead to filling of an existing, but empty, caffeine-sensitive pool of $\mathrm{Ca}^{2+}$. Thus, it seems likely that the astrocytes do not possess a caffeine-sensitive pool. As we also found that caffeine had no effect on responses to ATP, it is evident that the intracellular pool from which ATP causes release of $\mathrm{Ca}^{2+}$ is caffeine insensitive.

Thapsigargin also did not increase baseline levels of intracellular $\mathrm{Ca}^{2+}$. However, we found that ATP-evoked increases in $\left[\mathrm{Ca}^{2+}\right]_{i}$ were abolished by thapsigargin, indicating that ATP causes release of $\mathrm{Ca}^{2+}$ from a pool that is thapsigargin sensitive. Responses to ATP only partially recovered after about $1 \mathrm{hr}$. This prolonged and only partially reversible blockade by thapsigargin is consistent with its reported action of irreversibly blocking the activity of sarcoplasmic or endoplasmic reticulum $\mathrm{Ca}^{2+}$-ATPases (SERCA), possibly by covalent modification (Lytton et al., 1991). Previous studies on ATP-evoked release of $\mathrm{Ca}^{2+}$ have identified the intracellular pool only as being $\mathrm{IP}_{3}$ sensitive. Thus, the present report is the first to identify this pool as sensitive to thapsigargin.

In many types of cell thapsigargin has been found to increase resting $\left[\mathrm{Ca}^{2+}\right]_{i}$ (Thastrup et al., 1990), and thus our observation that it was unaffected by thapsigargin may seem surprising. However, because thapsigargin blocks pumping of $\mathrm{Ca}^{2+}$ into the pool, the lack of effect on resting $\mathrm{Ca}^{2}+$ levels may indicate that there is no ongoing pump activity or that the ongoing level of pumping is so low that other cellular buffering and pumping mechanisms can adequately compensate when SERCA pumps are blocked. The former seems unlikely as the response to ATP declined markedly even though ATP was not applied, suggesting that there is continual turnover in the thapsigargin-sensitive pool. As such, this turnover appears to be normally at a low level relative to $\mathrm{Ca}^{2+}$ buffering mechanisms. Consistent with this possibility, we found that responses decreased when cells were exposed to $\mathrm{Ca}^{2+}$-free media even before applying ATP. Thus, it appears that $\mathrm{Ca}^{2+}$ may be readily depleted from the thapsigargin-sensitive pool by removing extracellular $\mathrm{Ca}^{2+}$. 


\section{Electrophysiological effects of ATP on astrocytes}

Despite uniformity in the effects of ATP on $\left[\mathrm{Ca}^{2+}\right]_{i}$ in astrocytes, there was considerable diversity in the membrane currents evoked by ATP. The currents typically began after the start of the rise in $\left[\mathrm{Ca}^{2+}\right]_{i}$ and ATP-evoked currents could be eliminated when intracellular solutions with high levels of $\mathrm{Ca}^{2+}$ buffers were used. Thus, the currents induced by applying ATP may be $\mathrm{Ca}^{2+}$ activated currents. The possibility that these cells also have channels directly gated by ATP remains to be investigated. Calcium-activated nonselective cation channels have been reported in astrocytes (Puro, 1991), and such channels might account for the inward currents. The inward currents evoked by ATP may underlie its depolarizing action found on cultured cortical astrocytes (Magoski and Walz, 1992). Potassium channels activated by $\mathrm{Ca}^{2+}$ have also been reported in astrocytes (Quandt and MacVicar, 1986) and, given the ionic composition of the recording solutions, such channels would provide the simplest explanation for the outward currents elicited by ATP.

In some cells the current elicited by ATP was associated with no apparent change in membrane conductance. An explanation for this observation is that the current might be generated at a site electrotonically distant from the recording electrode where any conductance change could not be discerned. Alternatively, the lack of conductance change may indicate that the current is due to activation of an electrogenic pump or exchanger.

\section{ATP-evoked increases in $\left[\mathrm{Ca}^{2+}\right]_{\mathrm{i}}$ in dorsal horn neurons}

We found that ATP increased $\left[\mathrm{Ca}^{2+}\right]_{i}$ in $35 \%$ of dorsal horn neurons tested. Such restricted sensitivity to $\Lambda T P$ of only a subpopulation of dorsal horn neurons is characteristic of excitatory responses evoked by ATP in culture (Jahr and Jessell, 1983) and in vivo (Fyffe and Perl, 1984; Salter and Henry, 1985). The subpopulation of dorsal horn neurons excited by ATP is excited by inputs from low-threshold primary afferents, and the central terminals of such afferents appear to release ATP (Sawynok et al., 1993). The present results suggest that a physiological action of ATP may be to increase $\left[\mathrm{Ca}^{2+}\right]_{i}$ in the subset of dorsal horn neurons excited by low-threshold inputs. The increase in $\left[\mathrm{Ca}^{2+}\right]_{i}$ in dorsal horn neurons may be a consequence of depolarization, known to be caused by ATP (Jahr and Jessell, 1983), with subsequent activation of voltage-gated $\mathrm{Ca}^{2+}$ channels. Alternatively, as cationic channels directly activated by ATP are nonselective and permeable to $\mathrm{Ca}^{2+}$ (Bean, 1992), it is possible that the ATP-evoked increases in $\left[\mathrm{Ca}^{2+}\right]_{i}$ in dorsal horn neurons might be due to activation of channels that themselves allow $\mathrm{Ca}^{2+}$ influx.

\section{Significance of ATP-evoked responses in astrocytes}

As there is strong evidence that ATP is released from nerve terminals within the spinal dorsal horn (White et al., 1985; Sawynok et al., 1993), our results showing that ATP increases $\left[\mathrm{Ca}^{2+}\right]_{i}$ and activates membrane currents in astrocytes indicate a possible role for this molecule as a mediator of signaling from neurons to astrocytes in the dorsal horn. Increases in $\left[\mathrm{Ca}^{2+}\right]_{i}$ evoked by synaptic activity have been reported in astrocytes in the hippocampus (Dani et al., 1992), and in perisynaptic glia at the neuromuscular junction (Jahromi et al., 1992). The rise in $\left[\mathrm{Ca}^{2+}\right]$; may signal astrocytes to increase glucose metabolism (Arbones et al., 1990), to alter neurotransmitter uptake and metabolism (Vernadakis, 1988), or to secrete substances that feed back to affect neuronal excitability or regulate synaptic transmission (Martin, 1992).

Astrocytes have important roles in the reaction to damage and injury (Fedoroff and Vernadakis, 1986). Reactions of astrocytes to damage, including alterations in gene expression and proliferation, are regulated by $\left[\mathrm{Ca}^{2+}\right]_{i}$ (Neary et al., 1987; Arenander et al., 1989; Condorelli et al., 1989). Tissue injury is known to cause release of ATP and other adenine nucleotides (Gordon, 1986; El-Moatassim et al., 1992). Thus, the present results raise the additional possibility that ATP, or a related molecule, may be a mediator of astrocytic responses to injury via activation of $P_{2 Y}$ receptors with subsequent release of $\mathrm{Ca}^{2+}$ from thapsigargin-sensitive intracellular stores.

\section{Conclusions}

The present results indicate that ATP increases $\left[\mathrm{Ca}^{2+}\right]_{i}$ in astrocytes and, to a lesser extent, in neurons and oligodendrocytes. In astrocytes ATP appears to act on $\mathrm{P}_{2 \mathrm{Y}}$ purinergic receptors to cause release of $\mathrm{Ca}^{2+}$ from thapsigargin-sensitive stores. Our results indicate that $\mathrm{ATP}$ may act not only on neurons but also on astrocytes. Thus, ATP may play a role in neuronal-glial signaling within the spinal dorsal horn.

\section{References}

Agren G, Ronquist G (1974) (32-P) Phosphoryl transfer by endogenous protein kinase at the glia and glioma cell surface in culture into extrinsic acceptor proteins. Acta Physiol Scand 92:430-432.

Arbones L, Picatoste F, Garcia A (1990) Histamine stimulates glycogen breakdown and increases in $\mathrm{Ca}^{2+}$ permeability in rat astrocytes in primary culture. Mol Pharmacol 37:921-927.

Arenander AT, de Villis J, Herschman HR (1989) Induction of c-fos and TIS genes in cultured rat astrocytes by neurotransmitters. J Neurosci 24:107-114.

Bean BP (1992) Pharmacology and electrophysiology of ATP-activated ion channels. Trends Pharmacol Sci 13:87-90.

Benham CD (1989) ATP-activated channels gate calcium entry in single smooth muscle cells dissociated from rabbit ear artery. J Physiol (Lond) 419:689-701.

Benham CD, Tsien RW (1987) A novel receptor-operated $\mathrm{Ca}^{2+}$-permeable channel aclivated by ATP in smooth muscle. Nature 328: 275-278.

Berridge MJ (1993) Inositol trisphosphate and calcium signalling. Nature 361:315-325.

Burnstock $G$ (1978) A basis for distinguishing two types of purinergic receptor. In: Cell membrane receptors for drugs and hormones: a multidisciplinary approach (Straub RW, Bolis L, eds), pp 107-118. New York: Raven.

Burnstock G (1990) Purinergic mechanisms. Ann NY Acad Sci 603: $1-17$.

Burnstock G, Kennedy C (1985) Is there a basis for distinguishing two types of P2-purinoceptor? Gen Pharmacol 16:433 440.

Christie A, Sharma VK, Sheu S-S (1992) Mechanism of extracellular ATP-induced increase of cytosolic $\mathrm{Ca}^{2+}$ concentration in isolated rat ventricular myocytes. J Physiol (Lond) 445:369-388.

Cockcroft S, Gomperts BD (1980) The $\mathrm{ATP}^{4-}$ receptor of rat mast cells. Biochem J 188:789-798.

Condorelli DF, Kaczmarek L, Nicoletti $\mathbf{F}$, Avola R, Messina A, Giuffrida SAM (1989) Induction of protooncogene fos extracellular signals in primary glial cell cultures. J Neurosci Res 23:234-239.

Cusack NJ, Hourani SMO (1990) Subtypes of P2-purinoceptors. Studies using analogues of ATP. Ann NY Acad Sci 603:172-181.

Dani JW, Chernjavsky A, Smith SJ (1992) Neuronal activity triggers calcium waves in hippocampal astrocyte networks. Neuron 8:429440.

Den Hertog A, Van den Akker J, Nelemans A (1989) Suramin and the inhibitory junction potential in taenia caeci of the guinea-pig. Eur J Pharmacol 173:207-209.

Dunn PM, Blakeley AGH (1988) Suramin: a reversible $\mathrm{P}_{2}$-purinoceptor antagonist in the mouse vas deferens. Br J Pharmacol 93:243245. 
Edwards FA, Gibb AJ, Colquhoun D (1992) ATP receptor-mediated synaptic currents in the central nervous system. Nature 359:144-147.

Ehrlich YH, Davis TB, Bock E, Kornecki E, Lenox RH (1986) Ectoprotein kinase activity on the external surface of neural cells. Nature 320:67-69.

Fl-Moatassim C, Dornand J, Mani J-C (1992) Fxtracellular ATP and cell signalling. Biochim Biophys Acta Mol Cell Res 1134:31-45.

Evans RJ, Derkach V, Surprenant A (1992) ATP mediates fast synaptic transmission in mammalian neurons. Nature 357:503-505.

Fedan JS, Lamport SJ (1990) Two dissociable phases in the contractile response of the guinea pig isolated vas deferens to adenosine triphosphate. J Pharmacol Exp Ther 253:993-1001.

FedoroffS, Vernadakis A (1986) Astrocytes: cell biology and pathology of astrocyte. New York: Academic.

rok-Seang J, Miller KH (1992) Astrocyte precursors in neonatal rat spinal cord cultures. J Neurosci 12:2751-2764.

Fyffe RE, Perl ER (1984) Is ATP a central synaptic mediator for certain primary afferent fibers from mammalian skin? Proc Natl Acad Sci USA 81:6890-6893.

Gordon JL (1986) Extracellular ATP: effects, sources and fate. Biochem J 233:309-319.

Grynkiewicz G, Poenie M, Tsien RY (1985) A new generation $\mathrm{Ca}^{2+}$ indicators with greatly improved fluorescence properties. J Biol Chem 260:3440-3450.

Hansson E, Rönnbäck L (1989) Primary cultures of astroglia and neurons from different brain regions. In: A dissection and tissue culture manual of the nervous system (Shahar A, de Vellis J, Vernadakis A, Haber B, eds), pp 92-104. New York: Liss.

Harden TK, Boyer JL, Brown HA, Cooper CL, Jeffs RA, Martin MW (1990) Biochemical properties of a $P_{2 Y}$-purinergic receptor. Ann NY Acad Sci 603:256-266.

Hoiting B, Molleman A, Nelemans A, Den Hertog A (1990) P,-purinoceptor-activated membrane currents and inositol tetrakisphosphate formation are blocked by suramin. Eur J Pharmacol 181:127131.

Holton FA, Holton P (1954) The capillary dilator substances in dry powders of spinal roots; a possible role of adenosine triphosphate in chemical transmission from nerve endings. J Physiol (Lond) 126:124140.

Holton $\mathrm{P}$ (1959) The liberation of adenosine triphosphate on antidromic stimulation of sensory nerves. J Physiol (Lond) 145:494-504.

Horn R, Marty A (1988) Muscarinic activation of ionic currents measured by a new whole-cell recording method. J Gen Physiol 92:145159.

Hösli E, Hösli L (1993) Receptors for neurotransmitters on astrocytes in the mammalian central nervous system. Prog Neurobiol 40:477506.

Hoyle CH, Knight GE, Burnstock G (1990) Suramin antagonizes responses to $\mathrm{P} 2$-purinoceptor agonists and purinergic nerve stimulation in the guinea-pig urinary bladder and taenia coli. Br J Pharmacol 99: $617-621$.

Inoue K, Nakazawa K, Ohara-Imaizumi M, Obama T, Fujimori K, Takanaka A (1991) Selective and competitive antagonism by suramin of ATP-stimulated catecholamine-secretion from PC12 phaeochromocytoma cells. Br J Pharmacol 102:581-584.

Jahr CE, Jessell TM (1983) ATP excites a subpopulation of rat dorsal horn neurones. Nature 304:730-733.

Jahromi BS, Robitaille R, Charlton MP (1992) Transmitter release increases intracellular calcium in perisynaptic Schwann cells in situ. Neuron 8:1069-1077.

Jensen AM, Chiu SY (1990) Fluorescence measurement of changes in intracellular calcium induced by excitatory amino acids in cultured cortical astrocytes. J Neurosci 10:1165-1175.

Kastritsis CHC, Salm AK, McCarthy K (1992) Stimulation of the $P_{2 Y}$ purinergic receptor on type 1 astroglia results in inositol phosphate formation and calcium mobilization. J Neurochem 58:1277-1284.

Korn SJ, Horn R (1989) Influence of sodium-calcium exchange on calcium current rundown and the duration of calcium-dependent chloride currents in pituitary cells, studied with whole cell and perforated patch recording. J Gen Physiol 94:789-812.

Lai K-M, Wong PCL (1991) Metabolism of extracellular adenine nucleotides by cultured rat brain astrocytes. J Neurochem 57:15101515.

Lamport-Vrana SJ, Vrana KE, Fedan JS (1991) Involvement of ectophosphoryl transfer in contractions of the smooth muscle of the guinea pig vas deferens to adenosine 5'-triphosphate. J Pharmacol Exp Ther 258:339-348.

Lytton J, Westlin M, Hanley MR (1991) Thapsigargin inhibits the sarcoplasmic or endoplasmic reticulum Ca-ATPase family of calcium pumps. J Biol Chem 266:17067-17071.

MacDonald JF, Wang L.-Y, Salter MW (1993) Phosphorylation of glutamate receptors using electrophysiology techniques. Methods Neurosci, in press.

Magoski NS, Walz W (1992) Ionic dependence of a $\mathrm{P}_{2}$-purinoceptor mediated depolarization of cultured astrocytes. J Neurosci Res 32: 530-538.

Martin DL (1992) Synthesis and release of neuroactive substances by glial cells. Glia 5:81-94.

Mayer ML, Westbrook GL (1987) The physiology of excitatory amino acids in the vertebrate nervous system. Prog Neurobiol 28:197-276.

McCarthy KD, Salm AK (1991) Pharmacologically-distinct subsets of astroglia can be identified by their calcium response to neuroligands. Neuroscience 41:325-333.

Meldolesi J, Clementi E, Fasolato C, Zacchetti D, Pozzan T (1991) $\mathrm{Ca}^{2+}$ influx following receptor activation. Trends Pharmacol Sci 12 : 289-292.

Miller RH, Szigeti V (1991) Clonal analysis of astrocyte diversity in neonatal rat spinal cord cultures. Development 113:353-362.

Miller RJ (1991) The control of neuronal $\mathrm{Ca}^{2+}$ homeostasis. Prog Neurobiol 37:255-285.

Neary JT, del Pilar Gutierrez M, Norenberg LOB, Norenberg MD (1987) Protein phosphorylation in primary astrocyte cultures treated with and without dibutyryl cyclic AMP. Brain Res 410:164-168.

Neary JT, Van Breemen C, Forster E, Norenberg LOB, Norenberg MD (1988) ATP stimulates calcium influx in primary astrocyte cultures. Biochem Biophys Res Commun 157:1410-1416.

Neary JT, Laskey R, Van Breemen C, Blicharska J, Norenberg LOB, Norenberg MD (1991) ATP-evoked calcium signal stimulates protein phosphorylation/dephosphorylation in astrocytes. Brain Res 566: 89-94.

O'Connor SE, Dainty IA, Leff P (1991) Further subclassification of ATP receptors based on agonist studies. Trends Pharmacol Sci 12: $137-141$.

Pearce B, Murphy J, Morrow C, Dandona P (1989) ATP-evoked Ca ${ }^{2+}$ mobilisation and prostanoid release from astrocytes: $\mathrm{P}_{2}$-purinergic receptors linked to phosphoinositide hydrolysis. J Neurochem 52: 971-977.

Peterson ER, Crain SR (1982) Preferential growth of neurites from isolated fetal mouse dorsal root ganglia in relation to specific regions of cocultured spinal cord explants. Dev Brain Res 2:363-382.

Phillis JW, Wu PH (1981) The role of adenosine and its nucleotides in central synaptic transmission. Prog Neurobiol 16:187-239.

Puro DG (1991) A calcium-activated, calcium-permeable ion channel in human retinal glial cells: modulation by basic fibroblast growth factor. Brain Res 548:329-333.

Quandt FN, MacVicar BA (1986) Calcium activated potassium channels in cultured astrocytes. Neuroscience 19:29-41.

Ranscht B, Clapshaw PA, Price J, Noble M, Seifert W (1982) Development of oligodendrocytes and Schwann cells studied with a monoclonal antibody against galactocerebroside. Proc Natl Acad Sci USA 79:2709-2713

Ransom BR, Neale E, Henkart M, Bullock PN, Nelson PG (1977) Mouse spinal cord in cell culture. I. Morphology and intrinsic neuronal electrophysiologic properties. J Neurophysiol 40:1132-1150.

Salter MW (1992) ATP increases intracellular $\mathrm{Ca}^{2+}$ in cultured spinal cord glial cells studied using combined fluorescence and patch-clamp techniques. Int J Purine Pyrimidine Res 3:103.

Salter MW, Henry JL (1985) Effects of adenosine 5'-monophosphate and adenosine $5^{\prime}$-triphosphate on functionally identified units in the cat spinal dorsal horn. Evidence for a differential effect of adenosine 5 -triphosphate on nociceptive vs non-nociceptive units. Neuroscience 15:815-825.

Salter MW, Hicks JL (1992) Sccond messenger pathway for ATPevoked increases in intracellular $\mathrm{Ca}^{2+}$ in glia cultured from the dorsal spinal cord. Soc Neurosci Abstr 18:1000.

Salter MW, De Koninck Y, Henry JL (1993) Physiological roles for adenosine and ATP in synaptic transmission in the spinal dorsal horn. Prog Neurobiol 41:125-156.

Savitzky A, Golay JE (1964) Smoothing and differentiation of data by samplified least squares procedures. Anal Chem 36:1627-1639. 
Sawynok J, Downie JW, Reid AR, Cahill CM, White TD (1993) ATP release from dorsal spinal cord synaptosomes: characterisation and neuronal origin. Brain Res 610:32-38.

Silinsky EM, Gerzanich V, Vanner SM (1992) ATP mediates excitatory synaptic transmission in mammalian neurones. Br J Pharmacol 106:762-763.

Sneddon P, Burnstock G (1984) ATP as a co-transmitter in rat tail artery. Eur J Pharmacol 106:149-152.

Sneddon P, Westfall DP, Fedan JS (1982) Cotransmitters in the motor nerves of the guinea pig vas deferens: electrophysiological evidence. Science 218:693-695.

Stockbridge N (1987) EGTA. Comp Biol Med 17:299-304.

Stone TW (1981) Physiological roles for adenosine and adenosine 5'triphosphate in the nervous system. Neuroscience 6:523-555.

Tatham PER, Cusack NJ, Gomperts BD (1988) Characterization of the $\mathrm{ATP}^{4-}$ receptor that mediates permeabilisation of rat mast cells. Eur J Pharmacol 147:13-21.

Thastrup O (1990) Role of $\mathrm{Ca}^{2+}$-ATPases in regulation of cellular $\mathrm{Ca}^{2+}$ signalling, as studied with selective microsomal $\mathrm{Ca}^{2+}$-ATPase inhibitor thapsigargin. Agents Actions 29:1-2.

Thastrup O, Cullen PJ, Drobak BK, Hanley MR, Dawson AP (1990)
Thapsigargin, a tumor promoter, discharges intracellular $\mathrm{Ca}^{2+}$ stores by specific inhibition of the endoplasmic reticulum $\mathrm{Ca}^{2+}$-ATPase. Proc Natl Acad Sci USA 87:2466-2470.

Thayer SA, Sturek M, Miller RJ (1988) Measurement of neuronal $\mathrm{Ca}^{2+}$ transients using simultaneous microfluorimetry and electrophysiology. Pfluegers Arch 412:216-223.

Tsien RW, Lipscombe D, Madison DV, Bley KR, Fox AP (1988) Multiple types of neuronal calcium channels and their selective modulation. Trends Ncurosci 11:431-438.

Urbanek E, Nickel P, Schlicker E (1990) Antagonistic properties of four suramin-related compounds at vascular purine $\mathrm{P}_{2 \times}$ receptors in the pithed rat. Eur J Pharmacol 175:207-210.

Vernadakis A (1988) Neuron-glia interrelations. Int Rev Neurobiol 30:149-224.

Warf BC, Fok-Seang J, Miller RH (1991) Evidence for the ventral origin of oligodendrocyte precursors in the rat spinal cord. J Neurosci $11: 2477-2488$.

White TD, Downie JW, Leslie RA (1985) Characteristics of $\mathrm{K}^{+}$- and veratridine-induced release of ATP from synaptosomes prepared from dorsal and ventral spinal cord. Brain Res 334:372-374. 